\title{
Spatial variability of potassium in agricultural soils of the canton of Fribourg, Switzerland
}

\author{
Guillaume Blanchet ${ }^{\mathrm{a}}$, Zamir Libohova ${ }^{\mathrm{b}}$, Stéphane Joost ${ }^{\mathrm{c}}$, Nicolas Rossier ${ }^{\mathrm{d}}$, André Schneider ${ }^{\mathrm{e}}$, \\ Bernard Jeangros ${ }^{a}$, Sokrat Sinaj ${ }^{\mathrm{a}, *}$ \\ a Agroscope, Institute for Plant Production Sciences IPV, Route de Duillier 50, P.O. Box 1012, 1260 Nyon, Switzerland \\ b USDA-NRCS National Soil Survey Center, 100 Centennial Mall North, Federal Building, Room 152, Lincoln, NE 68508, United States

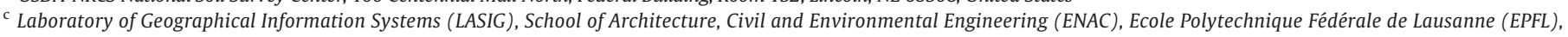 \\ Station 18, CH-1015 Lausanne, Switzerland \\ d Agricultural Institute of the Fribourg Canton, Route de Grangeneuve 31, 1725 Posieux, Switzerland \\ e Institut National de la Recherche Agronomique (INRA), UMR 1391 ISPA, CS 20032, F-33882 Villenave-d'Ornon cedex, France
}

\section{A R T I C L E I N F O}

\section{Article history:}

Received 9 June 2016

Received in revised form 25 November 2016

Accepted 1 December 2016

Available online $\mathrm{xxxx}$

\section{Keywords:}

Soil potassium

Soil properties

Terrain attributes

Land use

Spatial statistics

Autocorrelation

Random forest

\begin{abstract}
A B S T R A C T
Potassium $(\mathrm{K})$ is a crucial element for plant nutrition and its availability and spatial distribution in agricultural soils is influenced by many agro-environmental factors. In Switzerland, a soil monitoring network (FRIBO) was established in 1987 with 250 sites distributed over the whole of the canton of Fribourg (representing $4 \%$ of the surface area of Switzerland), whose territory is shared between the Swiss Midlands and the Western Alp foothills. In this study area, diverse geological deposits (sandstone, marlstone, silts and calcareous rocks), soil types (Cambisols, Gleysols, Rendzinas, Luvisols and Fluvisols) and land uses (cropland, permanent grassland and mountain pasture) are present, making the network interesting for assessing the relative contribution of environmental variables and land use management on soil properties. The aims of the present study were to (i) characterize the soil $\mathrm{K}$ status in the Fribourg canton according to four different extraction methods; (ii) analyse the spatial variability of soil $\mathrm{K}$ in relation to land use, soil type, soil parent material and topography; (iii) evaluate the spatial predictability of $\mathrm{K}$ at the canton level; and (iv) analyse the implications for K fertilization management. The overall amount of soil total $\mathrm{K}$ averaged $13.6 \mathrm{~g} \cdot \mathrm{kg}^{-1}$ with significant variations across the sites $\left(5.1-22.1 \mathrm{~g} \cdot \mathrm{kg}^{-1}\right)$. The spatial distribution of total $\mathrm{K}$ content was influenced by relatively extended soil forming processes, as suggested by (i) a significant global spatial autocorrelation measure at the $10 \mathrm{~km}$ scale (Moran's $I=$ 0.43); (ii) significant differences observed among soil types and soil parent materials and (iii) significant correlations with land attributes such as elevation $(r=-0.51)$. On the other hand, available mean $\mathrm{K}$ forms were significantly different among land uses, with the highest mean values of available $\mathrm{K}$ encountered in permanent grasslands, from $46.3 \mathrm{mg} \cdot \mathrm{kg}^{-1}$ (water extraction) to $198 \mathrm{mg} \cdot \mathrm{kg}^{-1}$ (acetate ammonium + EDTA extraction). All $\mathrm{K}$ forms (total and available) showed similar spatial regional patterns for all spatial interpolation methods, with areas dominated by permanent grassland and crops presenting higher values. However, these trends were less pronounced for the available $\mathrm{K}$ forms due to the prevalence of on-farm management practices for these $\mathrm{K}$ forms (e.g. fertilization), likely inducing high spatial and temporal variability. This hypothesis was supported by spatial clustering of low and/or high $\mathrm{K}$ fertility status that could be related to local particular farming practices. Grasslands require particular attention with regard to overall high $\mathrm{K}$ fertility status.
\end{abstract}

C 2016 Elsevier B.V. All rights reserved.

\section{Introduction}

Potassium (K) is a crucial element of plant nutrition and is the second largest nutrient assimilated by plants after nitrogen (Marschner, 2012). It is generally abundant in soil as it constitutes about $2 \%$ of the earth's crust (Schroeder, 1978). Not all of its forms, however, are readily available to plants. It is generally recognized that soil $\mathrm{K}$ occurs in soil in

\footnotetext{
* Corresponding author.

E-mail address: sokrat.sinaj@agroscope.admin.ch (S. Sinaj).
}

four forms: water-soluble, exchangeable, non-exchangeable and structural (Sparks, 1987; Syers, 2003). Among these different forms, dynamic equilibrium reactions control the release and/or fixation of K according to soil biogeochemical properties and processes (Zörb et al., 2014). Therefore, distribution of soil $\mathrm{K}$ forms is influenced by many agroenvironmental factors, such as soil parent materials (Askegaard et al., 2004; McLean and Watson, 1985; Öborn et al., 2005), degree of soil weathering (Andrist-Rangel et al., 2006; Barré et al., 2008; Johnston and Goulding, 1990), topography (Kozar et al., 2002; Winzeler et al., 2008) and nutrient balance (Bertsch and Thomas, 1985; Simonsson 
et al., 2007). Despite the natural abundance of $\mathrm{K}$ in soils (Askegaard et al., 2004; Schroeder, 1978), certain regions of the world, such as Australia, China and Iran, present crop K deficiencies over large areas due to particular pedoclimatic conditions or long-term underfertilization of K (Brennan and Bell, 2013; Hseung, 1980; Ji-yun, 1997; Malakouti, 1999; Römheld and Kirkby, 2010). In Europe, soil K deficiencies are not widespread (Tóth et al., 2013), but deficiencies or reduction of soil $\mathrm{K}$ are reported at the regional scale, especially in countries around the Baltic Sea and in the United Kingdom (Andrist-Rangel et al., 2010; Tóth et al., 2013). In Switzerland, there has been no study on soil K status on a national scale, as $\mathrm{K}$ deficiencies in crops are scarce and only reported at the plot scale. However, there are increasing concerns about the quality of fodder as a consequence of potential K over-fertilization (Kessler, 1997).

Understanding soil $\mathrm{K}$ status is important when developing appropriate K nutrient management. Potassium fertilization strategies and recommendations essentially rely on soil analyses using different extraction methods to assess its availability with respect to plant uptake and crop production. Nevertheless, the complex behavior of $\mathrm{K}$ in soil hinders assessment of $\mathrm{K}$ plant availability as each $\mathrm{K}$ form contributes to plant nutrition at different levels (Zörb et al., 2014). Current K fertilization recommendations are based on the amount of water-soluble $\left(\mathrm{K}_{\mathrm{W}}\right)$ or exchangeable $\mathrm{K}\left(\mathrm{K}_{\mathrm{AAE}}\right)$ (Sinaj et al., 2009; Mallarino et al., 2003), as these forms are considered readily available (Syers, 2003). The assessment of soil K availability by means of current soil tests is still under discussion as the $\mathrm{K}$ plant uptake could be limited under particular conditions (Blake et al., 1999; Franzen and Peck, 1997; Khan et al., 2014). There is evidence that other $\mathrm{K}$ forms (i.e. non-exchangeable and structural $\mathrm{K}$ ) may contribute significantly to plant nutrition (Bertsch and Thomas, 1985; Blake et al., 1999; Chatterjee et al., 2015; Jalali, 2007), especially when exchangeable $\mathrm{K}$ content is low (Schneider, 1997). Therefore, the evaluation of soil $\mathrm{K}$ fertility should take into consideration all different $\mathrm{K}$ forms (Chatterjee et al., 2015).

The recent availability of geo-referenced soil databases offers opportunities to improve the prediction of the spatial distribution of nutrients. Spatial investigation of soil nutrient fertility relies on geostatistical methods, which allow the continuous prediction of soil properties from a network of sampling points (Webster and Oliver, 2007). One of the most accepted and widely used method integrating auxiliary variables, for example elevation-derived terrain attributes and remote sensing data, is regression kriging (RK) (Hengl et al., 2004; McBratney et al., 2000; Odeh et al., 1994, 1995). Such method is capable of handling complex and extensive data by systematically and statistically analyzing patterns in the measured values (Breiman, 2001). However, generated patterns via interpolation techniques need to be validated independently and evaluated by experts with knowledge about the study area, in order to discriminate between patterns that result from purely statistical computations and patterns that are supported by natural processes or management induced.

Agriculture in the Fribourg canton is an important activity shaping the landscape and affecting the environment. In this context, $\mathrm{K}$ is an important nutrient for local agricultural activities such as dairy production in the alpine region and cash crop production in the plains (e.g. potatoes and sugar beets). In Switzerland, fertilization guidelines rely on the status of water-soluble and exchangeable K (Sinaj et al., 2009). An analysis of nutrient balance on a national scale established by Spiess (2011) suggests a current surplus of $\mathrm{K}$ in soil due to farming activities. However, no regional investigation of the different $\mathrm{K}$ forms has been yet conducted. The establishment of the FRIBO network since 1987, by the Agricultural Institute of the Fribourg canton for surveying soil quality (Rossier et al., 2012) provides an opportunity for conducting regional studies. The objectives of this study were to (i) characterize the soil $\mathrm{K}$ status in the Fribourg canton according to four different extraction methods; (ii) analyse the spatial variability of soil $\mathrm{K}$ in relation to land use, soil type, soil parent material and topography; (iii) evaluate the spatial predictability of $\mathrm{K}$ at the canton level; and (iv) analyse the implications for $\mathrm{K}$ fertilization management.

\section{Material and methods}

\subsection{Study area}

The Fribourg canton ( $1670 \mathrm{~km}^{2}$, i.e. $4 \%$ of Switzerland) is located in the western part of Switzerland $\left(46^{\circ} 4^{\prime} \mathrm{N} ; 7^{\circ} 5^{\prime} \mathrm{E}\right)$. It presents diversified landscapes as it is located at the interface between the Swiss Midlands (northwest part of the canton) and the Western Alps foothills (southeast part of the canton). The topography is characterized by gentle slopes on the northwest that gradually lead to steep slopes towards Westerns Alps foothills. According to the meteorological data (Meteosuisse IDAweb database, available at http://www.meteosuisse. admin.ch/), local climate is temperate continental with cold winters (lowest mean monthly temperature observed in January: $-3.1{ }^{\circ} \mathrm{C}$ ) and mild summers (highest mean monthly temperature observed in July: $17.6{ }^{\circ} \mathrm{C}$ ). The mean annual temperature reaches $8{ }^{\circ} \mathrm{C}$. On average, annual precipitation amounts to $1118 \mathrm{~mm}$ and monthly values range from $63 \mathrm{~mm}$ (February) to $129 \mathrm{~mm}$ (August). However, climatic conditions are not homogeneous across the study area, notably due to the topography, especially elevation. In the hilly and mountainous part (SE), conditions are generally colder and wetter. Similar to the climate, geological formations and soil types present a NW-SE gradient through the canton and are related to topography (Fig. 1). Regional geology is complex as a result of quaternary glaciation, glacier deposits and subsequent fluvial erosion (Signer et al., 2000) (Fig. 1a). The north-central part of the study area is characterized by low molasses-type hills covered by moraine deposits, whereas the southern part encompasses flysch regions and alpine regions on calcareous formations. Based on soil parent material, major soil types are Cambisols in the northcentral part of the study area and a composite of Regosols, Gleysols, Rendzinas and Lithosols (Fig. 1b). Locally, other soil types such as Luvisols and Fluvisols are also present.

The FRIBO network was established in 1987 by the Agricultural Institute of the Fribourg canton and aims at monitoring pedological and agro-environmental conditions across the canton (Rossier et al., 2012). This network includes 250 sampling sites evenly distributed along an approximate $2 * 2 \mathrm{~km}$ grid. Since 1987 , approximately 50 sites have been sampled each year. Thus, every 5 years, all the sites have been sampled within a "cycle". In the present study, the FRIBO data collection of the 5th cycle (2007-2011) was used. Five out of the 250 sites were removed from our analyses due to extreme soil organic matter (SOM) content, which induced outliers in the different measured $\mathrm{K}$ forms.

Among the 245 sampling sites of the 5th cycle, three different land uses are represented: 121 sites in croplands, 80 in permanent grasslands and 44 in mountain pastures (Fig. 1). Croplands were mostly cultivated according to a meadow-maize-wheat-barley-rapeseed rotation, but some sites included other crops such as tubers, vegetables, orchards and vineyards. Permanent grasslands encompassed meadows that have been established for at least 6 consecutive years. Mountain pastures relate to specific grasslands, were located in the steep areas of the alpine part of the canton and were mostly grazed during summer. The spatial distribution of land uses also followed a NW-SE gradient, similar to soil types and terrain characteristics (Fig. 1). On each site, management of $\mathrm{K}$ fertilization was performed according to the Swiss fertilization guidelines for crops and grassland (Sinaj et al., 2009), generally with chemical fertilizer (potassium chloride) in croplands and cattle manure in grasslands and mountain pastures.

\subsection{Soil sampling and analysis}

At each site, composite soil samples of the surface horizon $(0-20 \mathrm{~cm}$ for croplands and $0-10 \mathrm{~cm}$ for grasslands and mountain pastures) were derived from 25 soil cores sampled over an area of $100 \mathrm{~m}^{2}$. The 245 sites 


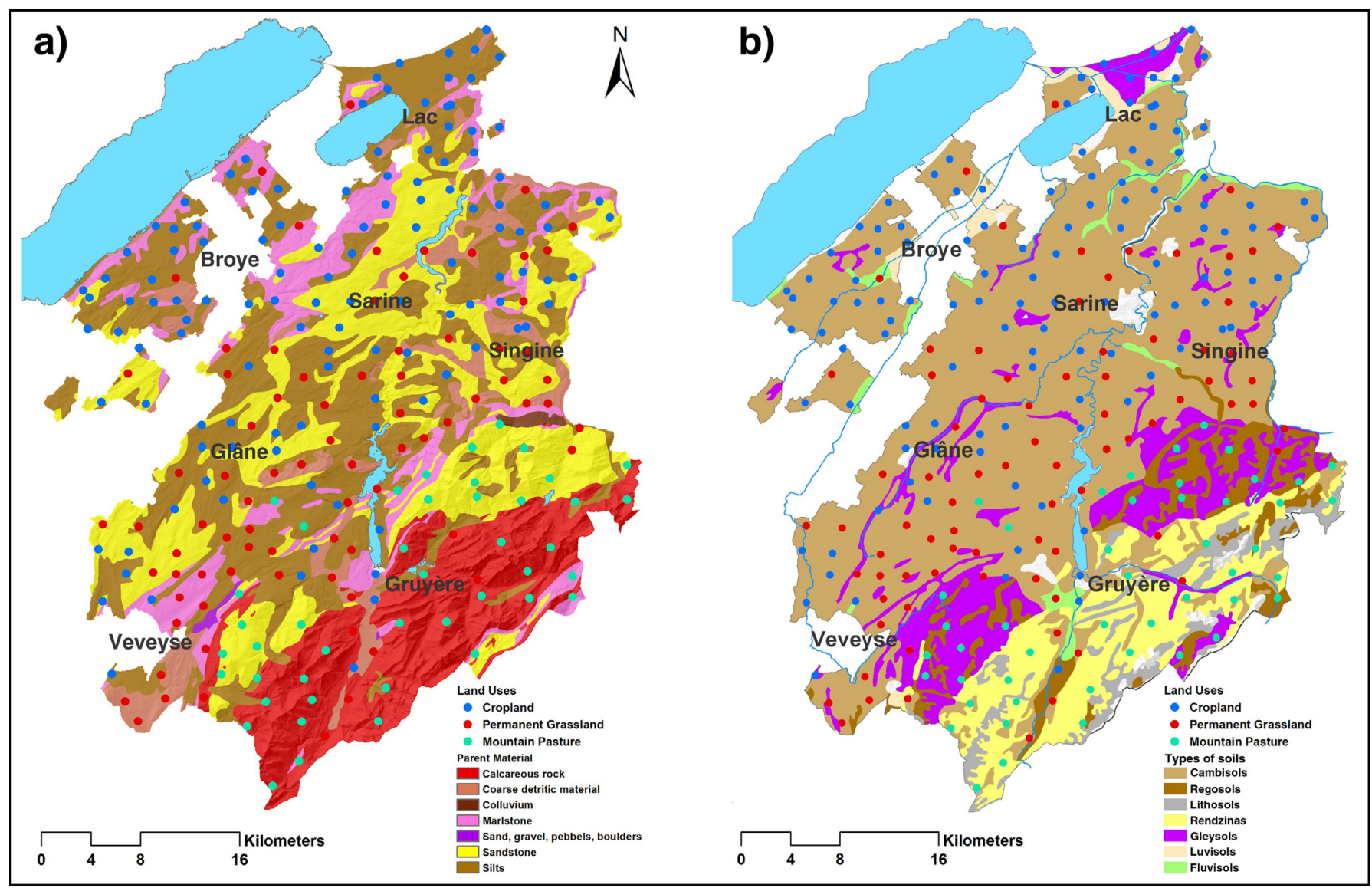

Fig. 1. (a) Geology and (b) soil map of the study area.

Table 1

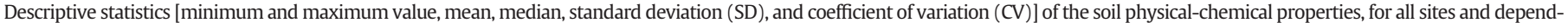
ing on land use. Different letters among land uses indicate a significant difference $(p<0.05)$ on a given variable, based on ANOVA followed by Tukey-Kramer pairwise comparisons test.

\begin{tabular}{|c|c|c|c|c|c|c|c|c|c|c|c|c|c|c|}
\hline & Altitude & Slope & & SOM & Clay & Sand & \multirow{2}{*}{$\begin{array}{l}\mathrm{CEC} \\
\mathrm{cmol} \cdot \mathrm{kg}^{-1}\end{array}$} & \multirow{2}{*}{$\begin{array}{l}\text { Sat }_{\text {CEC }} \\
\% \\
\end{array}$} & \multirow{2}{*}{$\frac{\mathrm{Ca}_{\mathrm{T}}}{\mathrm{g} \cdot \mathrm{kg}^{-1}}$} & \multirow[t]{2}{*}{$\mathrm{Mg}_{\mathrm{T}}$} & \multirow[t]{2}{*}{$\mathrm{K}_{\mathrm{T}}$} & \multirow{2}{*}{$\frac{\mathrm{K}_{\mathrm{AAE}}}{\mathrm{mg} \cdot \mathrm{kg}^{-1}}$} & \multirow[t]{2}{*}{$\mathrm{K}_{\mathrm{CO} 2}$} & \multirow[t]{2}{*}{$\mathrm{K}_{\mathrm{W}}$} \\
\hline & $\mathrm{m}$ & $\%$ & $\mathrm{H}_{2} \mathrm{O}$ & $\mathrm{g} \cdot \mathrm{kg}^{-1}$ & & & & & & & & & & \\
\hline \multicolumn{15}{|c|}{ All sites $(n=245)$} \\
\hline Min-Max & $430-1590$ & $0-75$ & $4.4-8.0$ & $12-177$ & $87-752$ & $21-772$ & $5.9-54.0$ & $17.2-100$ & $1.1-114$ & $2.5-15.7$ & $5.1-22.1$ & $52.2-788.3$ & $3.3-189.8$ & $11.0-237.2$ \\
\hline Mean & 783.8 & 10.46 & 6.28 & 45.60 & 229.32 & 447.08 & 18.60 & 60.95 & 7.74 & 5.43 & 13.6 & 175.8 & 24.9 & 37.7 \\
\hline Median & 713.0 & 6.00 & 6.10 & 42.00 & 200.00 & 477.00 & 15.70 & 60.50 & 4.99 & 5.19 & 14.1 & 159.6 & 16.6 & 29.3 \\
\hline SD & 276.2 & 13.23 & 0.72 & 26.05 & 112.02 & 156.04 & 9.28 & 16.73 & 11.88 & 1.73 & 2.7 & 91.8 & 23.2 & 27.0 \\
\hline CV (\%) & 35.3 & 126.46 & 11.41 & 57.14 & 48.85 & 34.90 & 49.87 & 27.46 & 153.52 & 31.91 & 20.1 & 52.2 & 93.3 & 71.7 \\
\hline \multicolumn{15}{|c|}{ Croplands $(n=121)$} \\
\hline Min-Max & $430-995$ & $0-25$ & $5.3-8.0$ & $12-136$ & $87-581$ & $111-772$ & $5.9-52.9$ & $21-100$ & $2.8-93.9$ & $2.9-11.5$ & $7.5-22.1$ & $62.6-417.0$ & $5.0-81.5$ & $11.0-91.6$ \\
\hline Mean & 610.5 & 5.60 & 6.50 & 28.38 & 180.39 & 515.88 & 13.66 & 61.84 & 8.03 & 5.27 & 14.7 & 159.5 & 25.1 & 34.8 \\
\hline Median & 610.0 & 4.00 & 6.30 & 25.00 & 163.00 & 533.00 & 12.30 & 59.80 & 4.98 & 4.94 & 14.6 & 149.4 & 19.9 & 29.7 \\
\hline SD & 118.3 & 6.33 & 0.70 & 15.03 & 74.00 & 121.66 & 6.50 & 17.93 & 11.87 & 1.47 & 2.4 & 64.9 & 16.5 & 16.5 \\
\hline CV (\%) & 19.4 & 113.02 & 10.72 & 52.95 & 41.02 & 23.58 & 47.58 & 28.99 & 147.81 & 27.82 & 16.2 & 40.7 & 65.5 & 47.5 \\
\hline Tukey rank & $\mathrm{c}$ & $\mathrm{b}$ & $\mathrm{a}$ & c & c & $\mathrm{a}$ & c & n.s & n.s & n.s & $\mathrm{a}$ & $\mathrm{b}$ & $\mathrm{a}$ & $\mathrm{b}$ \\
\hline \multicolumn{15}{|c|}{ Permanent grasslands $(n=80)$} \\
\hline Min-Max & $460-1015$ & $0-33$ & $5.2-7.7$ & $23-98$ & $113-752$ & $21-694$ & $10.2-51.7$ & $17.7-96.8$ & $2.6-114.0$ & $3.0-15.7$ & $6.4-20.4$ & $55.5-788.3$ & $3.3-189.8$ & $12.6-237.2$ \\
\hline Mean & 772.5 & 7.54 & 6.19 & 53.01 & 240.73 & 426.73 & 20.78 & 60.55 & 8.31 & 5.71 & 13.2 & 197.8 & 31.5 & 46.3 \\
\hline Median & 810.0 & 6.00 & 6.10 & 50.00 & 213.50 & 441.50 & 19.25 & 59.70 & 5.21 & 5.82 & 13.5 & 169.3 & 16.2 & 30.5 \\
\hline SD & 126.6 & 7.52 & 0.60 & 15.29 & 113.04 & 138.82 & 7.60 & 15.05 & 14.59 & 1.77 & 2.3 & 119.7 & 32.5 & 38.5 \\
\hline CV (\%) & 16.4 & 99.79 & 9.68 & 28.85 & 46.96 & 32.53 & 36.57 & 24.85 & 175.43 & 30.96 & 17.5 & 60.5 & 106.6 & 83.2 \\
\hline Tukey rank & $\mathrm{b}$ & $\mathrm{b}$ & $\mathrm{b}$ & $\mathrm{b}$ & $\mathrm{b}$ & $\mathrm{b}$ & $\mathrm{b}$ & n.s & $\mathrm{n} . \mathrm{s}$ & $\mathrm{n} . \mathrm{s}$ & $\mathrm{b}$ & $\mathrm{a}$ & $\mathrm{a}$ & $\mathrm{a}$ \\
\hline \multicolumn{15}{|c|}{ Mountain pastures $(n=44)$} \\
\hline Min-Max & $880-1590$ & $0-75$ & $4.4-7.2$ & $45-177$ & $190-654$ & $31-603$ & $13.6-54.0$ & $17.2-83.5$ & $1.1-16.0$ & $2.5-11.6$ & $5.1-18.1$ & $52.2-519.2$ & $4.2-84.7$ & $11.0-136.0$ \\
\hline Mean & 1275.3 & 29.14 & 5.84 & 79.45 & 343.16 & 294.86 & 28.26 & 59.20 & 5.89 & 5.35 & 11.3 & 180.5 & 14.0 & 29.9 \\
\hline Median & 1300.0 & 27.50 & 5.80 & 70.50 & 347.00 & 280.00 & 25.65 & 62.30 & 4.67 & 4.85 & 10.9 & 173.2 & 10.8 & 25.9 \\
\hline SD & 179.5 & 18.38 & 0.74 & 26.12 & 110.49 & 153.81 & 9.56 & 16.44 & 3.57 & 2.25 & 2.9 & 90.0 & 13.1 & 20.7 \\
\hline CV (\%) & 14.1 & 63.10 & 12.72 & 32.85 & 32.20 & 52.16 & 33.84 & 27.77 & 60.57 & 42.03 & 25.2 & 49.8 & 93.9 & 69.3 \\
\hline Tukey rank & $\mathrm{a}$ & $\mathrm{a}$ & c & $\mathrm{a}$ & $\mathrm{a}$ & c & $\mathrm{a}$ & n.s & $\mathrm{n} . \mathrm{s}$ & n.s & c & $\mathrm{ab}$ & $\mathrm{b}$ & $\mathrm{b}$ \\
\hline
\end{tabular}

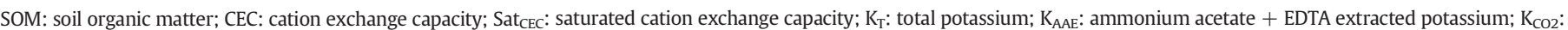
$\mathrm{CO}_{2}$-saturated water extracted potassium; $\mathrm{K}_{\mathrm{W}}$ : water extracted potassium. 
were sampled from 2007 to 2011 (about 50 sites per year). Plant residues were removed and samples were air-dried, sieved at $2 \mathrm{~mm}$ and further analysed for different soil chemical properties (Table 1 ). The $\mathrm{pH}-\mathrm{H}_{2} \mathrm{O}$, soil organic matter (SOM), clay and sand content, and cationexchange capacity (CEC) were measured according to standard methods (FAL et al., 2004).

Soil total calcium $\left(\mathrm{Ca}_{\mathrm{T}}\right)$, magnesium $\left(\mathrm{Mg}_{\mathrm{T}}\right)$ and $\mathrm{K}\left(\mathrm{K}_{\mathrm{T}}\right)$ concentrations were measured by digestion of $0.25 \mathrm{~g}$ of soil previously treated in $5 \mathrm{ml}$ of hydrofluoric acid (40\%) and $1.5 \mathrm{ml}$ of $\mathrm{HClO}_{4}$ (65\%) according to the AFNOR standard X31-147 (1996) followed by flame photometry measurement. Soil available K forms were evaluated by three methods used in routine analyses. The first method operated at an acidic $\mathrm{pH}$ in the presence of ammonium acetate and EDTA as a complexing agent (FAL et al., 2004, $\mathrm{K}_{\mathrm{AAE}}$ ), the second was performed with a 2.5 soil:extractant ratio for $1 \mathrm{~h}$ using $\mathrm{CO}_{2}$-saturated nanopure water at pH 3.5-4 and $\mathrm{p}_{\mathrm{CO} 2}$ of 6 bars (FAL et al., 2004, $\mathrm{K}_{\mathrm{CO} 2}$ ) and the third was performed with a 1:10 soil:water ratio for $16 \mathrm{~h}$ (FAL et al., 2004, $\mathrm{K}_{\mathrm{W}}$ ).

\subsection{Environmental variables for spatial predictions of potassium forms}

The Digital Elevation Model (DEM) of the study area is the SwissAlti3D produced by swisstopo (http://www.swisstopo.admin.ch/ ) with an original spatial resolution of $5 \mathrm{~m}$. It was projected to the CH1903 Hotine Oblique Mercator Azimuth Center Geographic Coordinate System. Using bilinear interpolation, the $5 \mathrm{~m}$ grid resolution was resampled to $30 \mathrm{~m}$, which is similar to the resolution suggested by a study conducted by Roger et al. (2014) in the same area, in order to reduce noise in the elevation data. Terrain attributes (slope, slope length, mid-slope position, curvature, planform curvature, profile curvature, standardized height, normalized height, SAGA Wetness Index, Vector Terrain Ruggedness, and Terrain Ruggedness) were used as environmental variables for $\mathrm{K}$ spatial predictions and processed with the System for Automated Geospatial Analysis (SAGA) (Conrad, 2006). Additionally, soil type, land use and soil parent material were used as environmental variables. The values of environmental variables were extracted for all 245 sites with measured $\mathrm{K}$ forms in order to investigate their spatial relationships for K predictions.

\subsection{Statistical analyses}

\subsubsection{Classical statistics}

Based on land use category, the mean, median, standard deviation and coefficient of variation for soil physicochemical properties and $\mathrm{K}$ forms were calculated for the entire dataset (Table 1 ). In addition, a principal component analysis (PCA) was performed on the multivariate dataset to investigate the correlations among the different variables and the projection of the 245 sites in the plan 1-2 of the PCA according to land use (Fig. 2). A one-way analysis of variance (ANOVA), followed by the Tukey-Kramer test for pairwise comparisons, was used to detect whether both the soil physicochemical properties and the K forms were significantly different depending on environmental variables. All statistical analyses were performed on R Version 3.2.1 (R Core Team, 2014) using the packages "vegan" (Oksanen et al., 2015) and "agricolae" (de Mendiburu, 2015).

\subsubsection{Spatial analysis}

2.4.2.1. Local indicators of spatial association. Using the geographical coordinates of the 245 sampling sites constituting the FRIBO database, the local spatial dependence of $\mathrm{K}_{\mathrm{T}}$ and $\mathrm{K}_{\mathrm{W}}$ was measured with the help of the Geoda software (Anselin and McCann, 2009). To this end we used Local Indicators of Spatial Association (LISA) developed by Anselin (1995), which are statistics that measures local spatial autocorrelation and evaluates the existence of local clusters of similar behavior in the spatial arrangement of a given variable. LISA are based on the statistical index I developed by Moran (1950) that measures the global spatial autocorrelation of the data in the area under investigation. Moran's I ranges from -1 (complete negative spatial autocorrelation) to 1 (complete positive spatial autocorrelation), with 0 indicating the absence of spatial dependence.

For each sampling site, the correlation between the observed variable and the mean of this variable in a given neighborhood was calculated. The standardized scattergram of this relationship shows four distinct classes: a) high observed values correlated with high values in the neighborhood (high-high), b) low observed values correlated with low values in the neighborhood (low-low), c) low-high relationships and d) high-low relationships. The attribution of individuals to these four classes depends on the results of a significance test, which consists of performing a large number of Monte-Carlo random permutations among locations to compare the observed LISA to the many LISA corresponding to the random permutations [see details in Anselin (1995)]. According to the sampling scheme, to the distance for which there is no neighborless sampling unit $(3.485 \mathrm{~km})$ and to the obtained correlogram, it was decided to analyse $\mathrm{K}$ within $10 \mathrm{~km}$ around each sampling point, similarly to the study of Roger et al. (2014). In addition, this distance is deemed representative of the spatial scale of regional soil forming processes.

2.4.2.2. Interpolation methods. In order to determine the multi-colinearity among environmental variables derived from DEM for $\mathrm{K}$ form spatial predictions, a multivariate analysis was conducted. The best predictors for the $\mathrm{K}$ forms were determined based on step-wise multiple linear regression (MLR) and Random Forest (RF) (Liaw and Wiener, 2002). The best predictors for various $K$ forms for the step-wise MLR were based on the minimum Akaike Information Criterion (AIC) (Akaike, 1976). For the $\mathrm{K}_{\mathrm{T}}$ the step-wise MLR was conducted on the untransformed data, while for the available $\mathrm{K}$ forms ( $\mathrm{K}_{\mathrm{AAE}}$ and $\mathrm{K}_{\mathrm{W}}$ ) the analysis was conducted on logit transformed to assure normal distribution of the data using JMP Version 11.0 (SAS Institute Inc., Cary, NC) statistical package. The RF was conducted on R Version 3.2.1 (R Core Team, 2014) with the "randomForest" package (Liaw and Wiener, 2002). The initial number of trees was specified to 100 and was adequate based on the error trend assessment. The spatial structure of $\mathrm{K}$ forms was determined by means of a semi-variogram using the nugget/sill ratio as defined by Cambardella et al. (1994). The structure of the spatial dependence and residuals was modelled in VESPER based on automated variogram fitting (Minasny and McBratney, 2002). No anisotropy was found among the selected variables, therefore isotropy was assumed for all kriging calculations. Semi-variograms were fitted with the best model. Spatial interpolation using ordinary kriging (OK) was performed in addition to regression-kriging for the step-wise MLR model, as suggested by Hengl et al. (2004), Odeh et al. (1994, 1995), and RF model. The RK interpolation (MLR and RF) and OK were tested to see if the models were consistent in the identification of best predictors and generated comparable predictions. The maps of predicted $\mathrm{K}$ forms and error residuals from the MLR and RF models were summed together to yield the final spatial predicted maps. The final predicted maps were back transformed. The $95 \%$ confidence limits of the predictions for the logit-transformed values were derived from Eq. (1) (Hengl et al., 2004).

$$
\hat{z} \pm t\left(s_{0}\right)=\frac{e^{\left[\hat{z}++\left(S_{0}\right) \pm t \sigma_{E}^{++}\left(S_{0}\right)\right]}}{1+e^{\left[\hat{z}++\left(S_{0}\right) \pm t \sigma_{E}^{++}\left(S_{0}\right)\right]}} *\left(z_{\max }-z_{\min }\right)+z_{\min }
$$

Where $t$ is the threshold value of standard normal error and $\sigma_{E}^{++}\left(s_{0}\right)$ is the standard deviation of the prediction error of logit transformed $\mathrm{K}$ forms. The $95 \%$ confidence limits of predicted maps were back transformed.

Leave one out cross-validation was performed on both step-wise MLR and RF. This method is the full $\mathrm{K}$-fold with $\mathrm{K}$ equal to the number of point observations. It was selected due to the limited number of points measured data relative to the study area size $\left(1\right.$ per $\left.6.8 \mathrm{~km}^{2}\right)$. 


\section{Results and discussion}

\subsection{Soil properties and potassium status}

Soils of the study area exhibited diverse physicochemical properties, as suggested by coefficients of variation (CV) higher than $25 \%$ for most of the investigated parameters (Table 1 ). The variability of soil properties decreased within each land use. For instance, soil texture of croplands was mostly sandy loamy to loamy (88.4\% of the sites) and associated with low SOM content, whereas mountain pastures were generally located on more clayey soil with relatively high SOM content (Table 1). In addition, soils were on average more acidic in mountain pastures $(\mathrm{pH}=5.8)$ than in croplands $(\mathrm{pH}=6.5)$. All these environmental variables could greatly influence the availability of soil $\mathrm{K}$ forms and the equilibrium rates between the different $\mathrm{K}$ pools. Clay content, CEC and SOM directly influence the K fixing capacity of soils as they relate to the fixing sites of cations (Ghiri and Abtahi, 2012; Schneider, 2003; Van Diest, 1978; Zhang et al., 2009). Climate, elevation and slope may also influence water run-off and infiltration and thus impact $\mathrm{K}$ leaching and its availability (Winzeler et al., 2008).

The overall K status of FRIBO soils is presented in Table 1. Among the different $\mathrm{K}$ forms, $\mathrm{K}_{\mathrm{T}}$ showed the lowest variability across the canton $(\mathrm{CV}=20.1 \%)$, whereas available $\left(\mathrm{K}_{\mathrm{AAE}}, \mathrm{K}_{\mathrm{CO} 2}\right.$ and $\left.\mathrm{K}_{\mathrm{W}}\right)$ forms appeared to fluctuate more (CV $>50 \%$ ). Total potassium averaged $13.6 \mathrm{~g} \cdot \mathrm{kg}^{-1}$ and ranged from 5.1 to $22.1 \mathrm{~g} \cdot \mathrm{kg}^{-1}$ across the study area. These results are in agreement with the observations made by Sparks (2001), who reported that most agricultural soils exhibit $K_{\mathrm{T}}$ content between 0.4 and $30 \mathrm{~g} \cdot \mathrm{kg}^{-1}$. Within each land use (Table 1 ), the highest values were observed in croplands (mean $\mathrm{K}_{\mathrm{T}}=14.7 \mathrm{~g} \cdot \mathrm{kg}^{-1}$ ) and the lowest in mountain pastures (mean $\mathrm{K}_{\mathrm{T}}=11.3 \mathrm{~g} \cdot \mathrm{kg}^{-1}$ ). Total $\mathrm{K}$ was also significantly correlated with some soil properties such as soil texture $\left(r_{\text {sand }}=0.50\right)$ and SOM $(r=-0.51)$ (Fig. 2$)$ and with elevation $(r=-0.51)$, suggesting that regional soil forming processes influenced by soil types and soil parent materials were important contributors to $\mathrm{K}_{\mathrm{T}}$ spatial distribution (Fig. 3). After ranking soil types according to their $\mathrm{K}_{\mathrm{T}}$ content of the upper soil layer (Fig. 3), an evolutionary soil sequence was noticed: poorly evolved soils with a thin organic-mineral horizon [i.e.

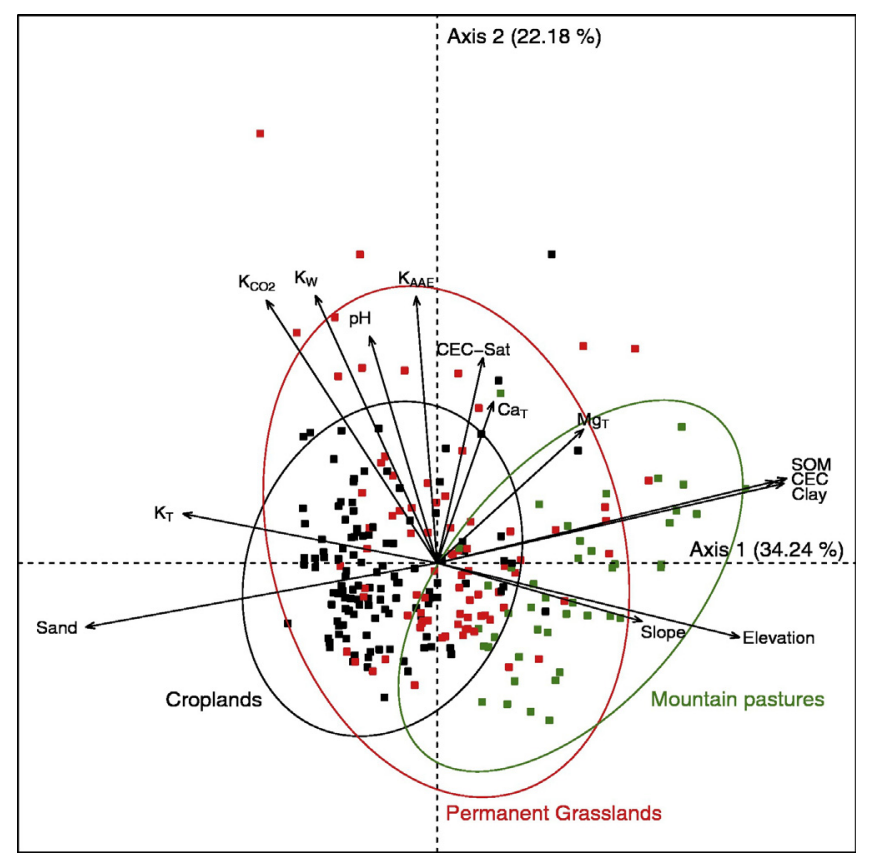

Fig. 2. Principal component analysis of main soil and environmental variables and $\mathrm{K}$ forms $(n=245)$.
Rendzina(s)] were associated on average with low $\mathrm{K}_{\mathrm{T}}$ content (mean $\mathrm{K}_{\mathrm{T}}=10.06 \mathrm{~g} \cdot \mathrm{kg}^{-1}$ ), whereas soils with more differentiated profiles [i.e. Cambisol(s)] presented higher $\mathrm{K}_{\mathrm{T}}$ content (mean $\mathrm{K}_{\mathrm{T}}=$ $14.23 \mathrm{~g} \cdot \mathrm{kg}^{-1}$ ). Other studies (Rezapour et al., 2010; Srinivasarao et al., 2007; Zhang et al., 2009) have also reported significant differences of total $\mathrm{K}$ content among different soil types, mainly due to soil texture and soil mineralogy.

In addition, the $\mathrm{K}_{\mathrm{T}}$ content showed significant differences among different soil parent materials (Fig. 3). On average, the highest $\mathrm{K}_{\mathrm{T}}$ value was observed on marlstone formations (mean $\mathrm{K}_{\mathrm{T}}=15.44 \mathrm{~g} \cdot \mathrm{kg}^{-1}$ ) whereas the lowest was reported for bedrock composed of sedimentary calcareous formations (mean $\mathrm{K}_{\mathrm{T}}=9.94 \mathrm{~g} \cdot \mathrm{kg}^{-1}$ ). These values were consistent with the results of Malavolta (1985) who reported that among sedimentary rocks, clayey rocks had generally higher $\mathrm{K}$ content than calcareous rocks. In another study in Scotland, Andrist-Rangel et al. (2010) reported that, among different geological deposits composed of sedimentary and igneous rocks, soils located on low-grade metamorphic argillaceous rocks presented the highest soil K content. In our study area, soil parent material and soil types were sometimes strongly related [e.g. most of the Rendzinas are located on calcareous rocks (Fig. 1)], but such observation was only restricted to elevated mountain area, in the Gruyère region. Thus, in addition to land use, subsoil features, and especially soil parent material, are likely to have a great influence on the spatial distribution of $\mathrm{K}_{\mathrm{T}}$.

Available forms of $\mathrm{K}\left(\mathrm{K}_{\mathrm{AAE}}, \mathrm{K}_{\mathrm{CO} 2}\right.$ and $\left.\mathrm{K}_{\mathrm{W}}\right)$ varied considerably across the canton and presented a coefficient of variation (CV) higher than $50 \%$. Such variability has already been reported at field and/or region scales (Lauzon et al., 2005; Wilding and Drees, 1983), with an increased variability at larger scales (Wilding and Drees, 1983). The correlation between $\mathrm{K}_{\mathrm{CO} 2}$ and $\mathrm{K}_{\mathrm{W}}$ (Fig. 2$)$ was very high $(r=0.96)$ and confirmed the similarity between these two extraction methods. The observed differences between land use could be attributed to differentiated fertilization practices and soil characteristics, especially regarding SOM and soil texture (Table 1), as suggested by Grimme and Németh (1978). In Switzerland, recommendations for $\mathrm{K}$ fertilization of crops and grasslands rely essentially on soil $\mathrm{K}$ analyses, involving either AAE- or $\mathrm{CO}_{2}$-extraction (Sinaj et al., 2009). Present results show that simple $\mathrm{H}_{2} \mathrm{O}$-extraction extracted on average more $\mathrm{K}$ than $\mathrm{CO}_{2}$ extraction $(+51.4 \%$ ) with a lower CV (Table 1$)$, highlighting the higher reliability of the first method for the estimation of available K. This was attributed to differences in the experimental protocol of the two methods, especially (i) the soil:extractant ratio (Sinaj et al., 1999) and (ii) the extraction time, which is much longer in case of $\mathrm{K}_{\mathrm{W}}$. In addition, water extraction was considered to be more representative of the $\mathrm{K}$ concentration in the soil solution $\left(\mathrm{K}^{+}\right)$. Therefore, only the results of $\mathrm{K}_{\mathrm{W}}$ and $\mathrm{K}_{\mathrm{AAE}}$ forms are discussed hereafter. According to the Swiss fertilization guidelines (Sinaj et al., 2009), overall soil K fertility of the FRIBO network appeared to be mostly "satisfying" for agronomical purposes (Fig. 4). However, these results need to take into account $\mathrm{K}$ forms and/ or land use. The agronomical appreciation of soil $\mathrm{K}$ was better differentiated with $K_{w}$ than with $K_{A A E}$. This is consistent with the absolute values presented in Table 1 and with $C V$ higher for $K_{W}$ than for $K_{\mathrm{AAE}}$. Soil K fertility was significantly higher in permanent grasslands compared to croplands (Table 1 and Fig. 4). Mountain pastures also contained more $\mathrm{K}_{\mathrm{AAE}}$ than croplands but similar amounts of $\mathrm{K}_{\mathrm{W}}$, probably reflecting higher fixation of soil $\mathrm{K}$ in mountain areas due to higher clay and SOM content (Schneider, 1997; Zhang et al., 2009). The overall high $\mathrm{K}$ fertility status observed in permanent grasslands and mountain pastures is likely to be related to the frequent use of organic manure, similar to observations made by Roger et al. (2014) for P. In these sites, amendments are applied based on the manure's nitrogen (N) and P budget (needs/inputs) at the farm level. This approach, implemented in Switzerland in the 1990s as part of the direct payment scheme, uses estimated needs of crops and grasslands and the total inputs by mineral and organic fertilizers for balancing nutrient fluxes at the farm scale (Übersax and Schüpbach, 2004). However, such 


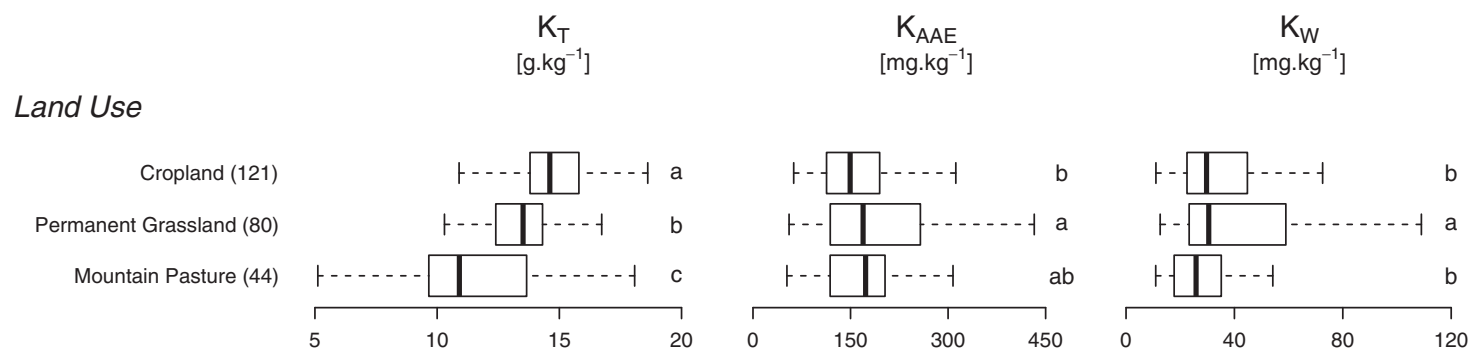

\section{Pedology}
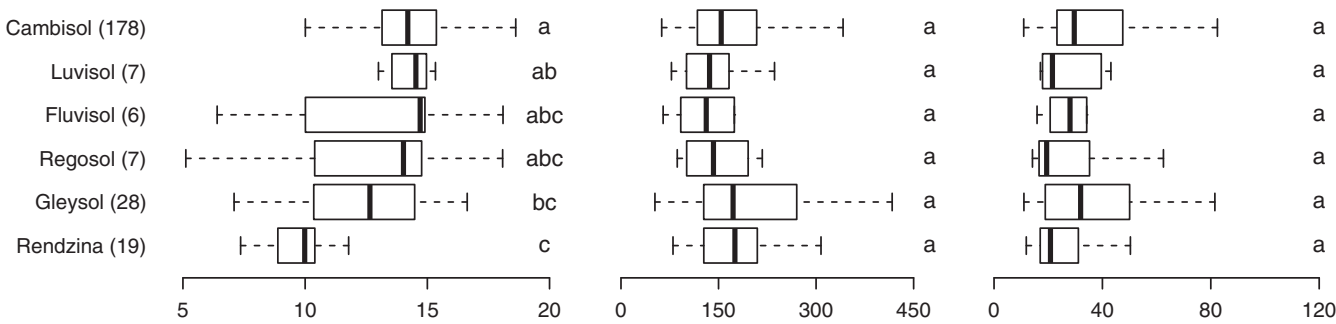

\section{Soil parent material}
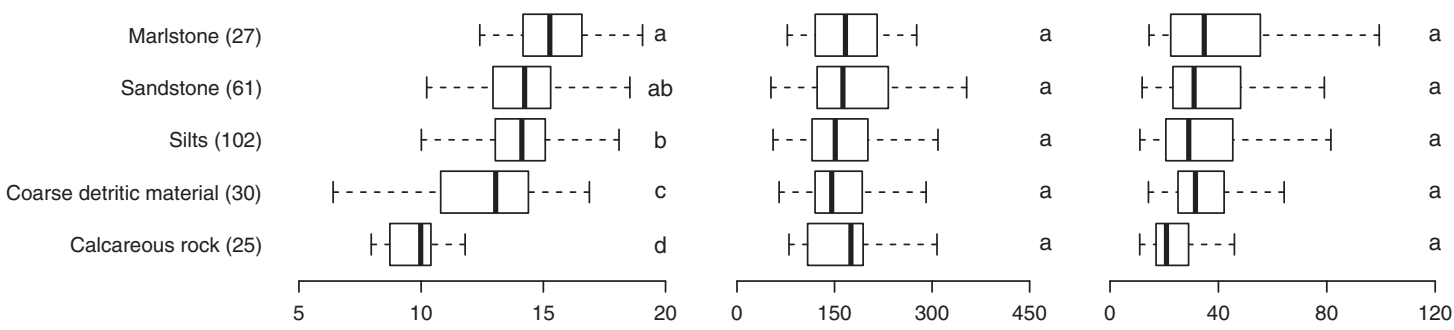

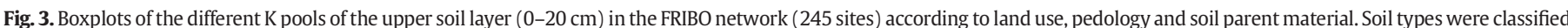

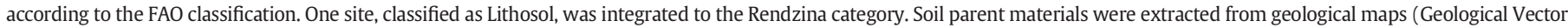

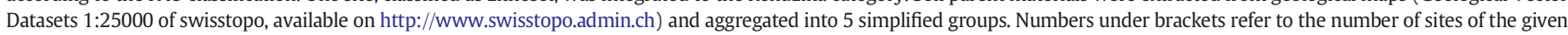
category. Letters correspond to Tukey's groups: different letters indicate significant differences at $p<0.05$.

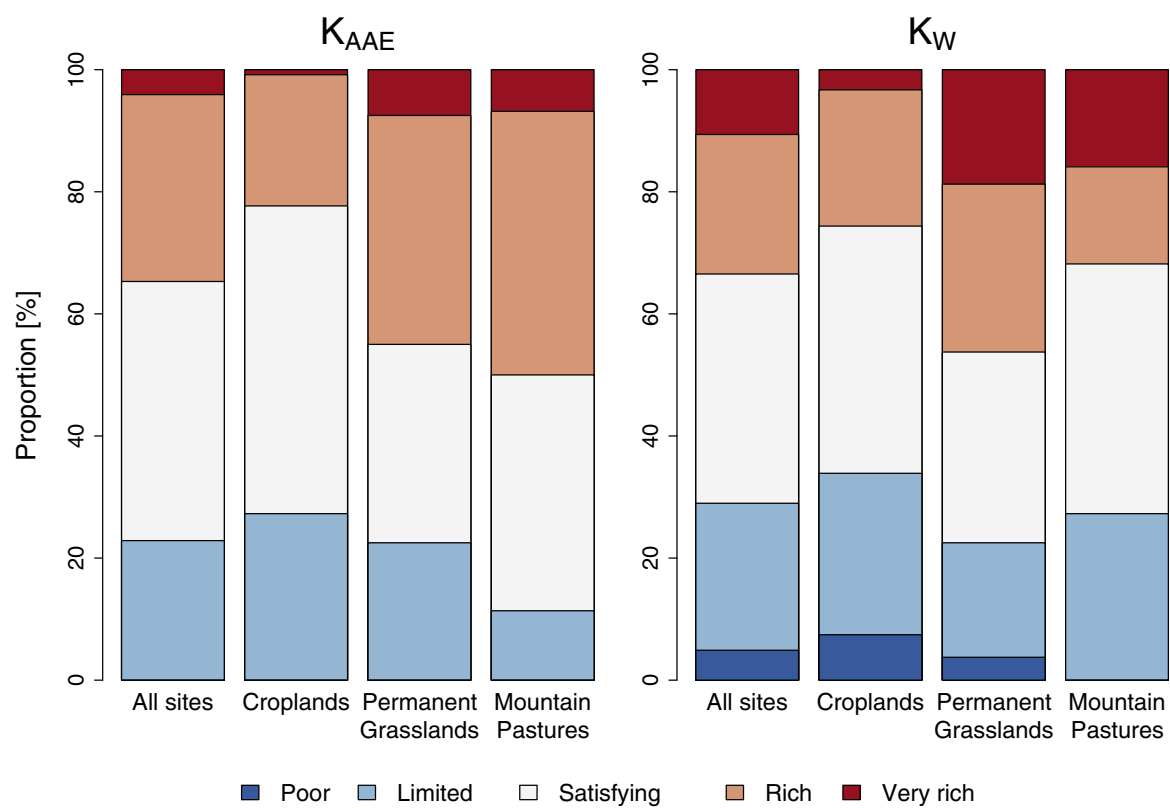

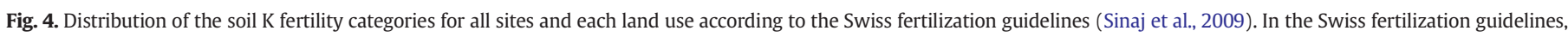

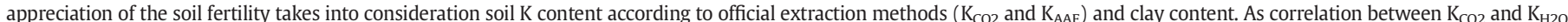

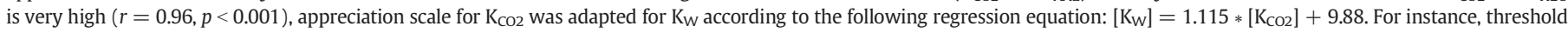

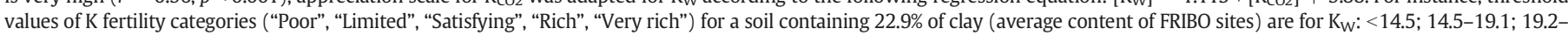
33.0; 33.0-65.4; >65.4 (in $\mathrm{mg} \mathrm{K} \cdot \mathrm{kg}^{-1}$ ). 
fertilization strategies, with a particular focus on $\mathrm{N}$ and $\mathrm{P}$, can lead to greater than necessary applications of $\mathrm{K}$, as suggested by Alfaro et al. (2003), Rossier et al. (2012) and Spiess (2011). In addition, Alfaro et al. (2004) showed that the type of fertilizer (organic or inorganic) could influence the leaching pattern of $\mathrm{K}$ in soil, as $\mathrm{K}$ bound to organic matter may be leached only when an equilibrium with the soil is reached. This may result in temporary $\mathrm{K}$ accumulation in the upper soil layer.

$\mathrm{K}_{\mathrm{AAE}}$ and $\mathrm{K}_{\mathrm{W}}$ were significantly and positively correlated with the soil $\mathrm{pH}$ but not with other environmental variables (Fig. 2). The poor correlation with soil clay content was interpreted as the consequence of two factors: (i) the greater importance of clay mineralogy in comparison to clay content with regards to K availability in this study area and (ii) a generalized unbalanced $\mathrm{K}$ fertility status across the canton, which probably buffered the $\mathrm{K}$ dependence to clay content. These hypotheses were supported by significant correlations between available $\mathrm{K}$ and the proportion of K-bearing clay minerals measured on a few sites (data not shown), as well as the overall unbalanced $\mathrm{K}$ fertility status (Fig. 4). Contrary to $\mathrm{K}_{\mathrm{T}}$, neither $\mathrm{K}_{\mathrm{AAE}}$ nor $\mathrm{K}_{\mathrm{W}}$ contents presented any significant differences with regards to soil types or soil parent materials (Fig. 3), because fertilization practices have a greater influence on available $\mathrm{K}$ than on total $\mathrm{K}$ and consequently mask the effect of the soil types and/or soil parent materials.

In summary, all $\mathrm{K}$ forms appeared to be influenced by land use, but in different ways (Table 1). In addition, pedological and geological attributes revealed interesting patterns for $\mathrm{K}_{\mathrm{T}}$, but not for the other investigated $\mathrm{K}$ forms (Fig. 3 ). $\mathrm{K}_{\mathrm{T}}$ of the upper soil layers was thus inferred to be mostly influenced by intrinsic factors (terrain attributes, soil type and soil parent material), whereas $\mathrm{K}_{\mathrm{AAE}}$ and $\mathrm{K}_{\mathrm{W}}$ were rather the consequence of extrinsic factors (land use). In order to confirm these hypotheses, an evaluation of the feasibility of spatial prediction of $\mathrm{K}$ forms at the canton level was made by performing additional spatial analyses.

\subsection{Spatial autocorrelation of soil potassium forms}

Analysis of global spatial autocorrelation revealed different spatial dependencies of soil $\mathrm{K}$ forms. Computation of global Moran's I values showed that distribution of $\mathrm{K}_{\mathrm{T}}$ was more auto correlated $\left(\mathrm{I}_{10} \mathrm{~km}=\right.$ 0.43 ) across the Fribourg canton, compared to $\mathrm{K}_{\mathrm{AAE}}$ and $\mathrm{K}_{\mathrm{W}}$ with $\mathrm{I}_{10 \mathrm{~km}}=-0.02$ and $\mathrm{I}_{10} \mathrm{~km}=0.03$, respectively. According to LISA analyses, clear spatial structures emerged for $\mathrm{K}_{\mathrm{T}}$ and $\mathrm{K}_{\mathrm{W}}$ (Fig. 5), whereas no structure could be observed for $K_{\mathrm{AAE}}$ (Fig. A). In the case of $\mathrm{K}_{\mathrm{T}}$ (Fig. $5 b$ ), there was a clear distinction between one cluster of high $\mathrm{K}_{\mathrm{T}}$ values in the northern third of the canton and another cluster of low $\mathrm{K}_{\mathrm{T}}$ values in the southern third. Sites with no particular spatial dependence were located in the central part. The situation and the extent of these two clusters confirmed statistically the observations made previously and supported the hypothesis that $\mathrm{K}_{\mathrm{T}}$ is mostly influenced by intrinsic factors, such as elevation and soil parent material. In addition, the two clusters covered areas where land uses were mixed; this suggests a relatively lower influence of farming activities on $\mathrm{K}_{\mathrm{T}}$.

Despite an overall poor spatial autocorrelation of $\mathrm{K}_{\mathrm{W}}$, two significant clusters emerged: one around the Broye region, indicating a particularly
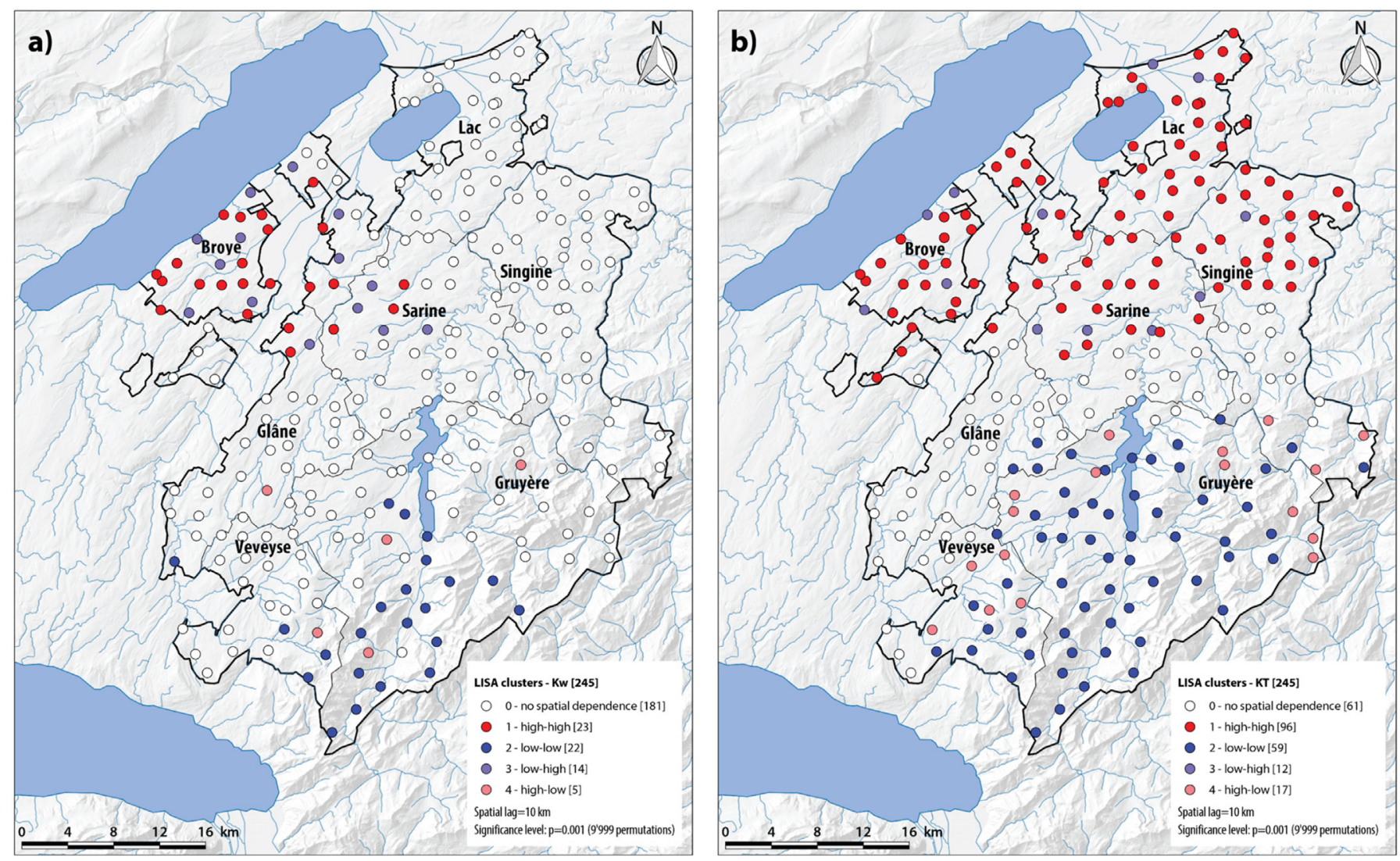

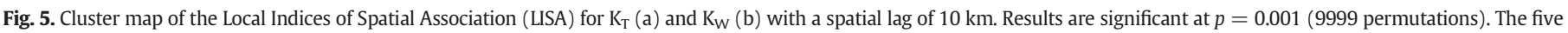

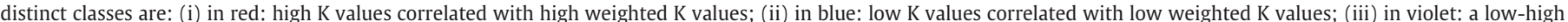

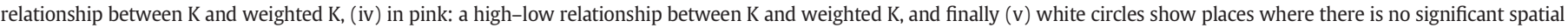

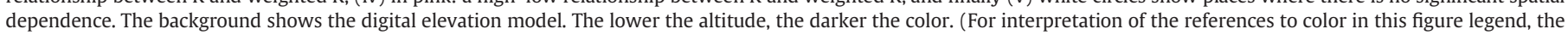
reader is referred to the web version of this article.) 
high $K_{W}$ environment, and another at the south of the Gruyère Lake, characterized by sites with low $\mathrm{K}_{\mathrm{W}}$ content. Similar trends with respect to $\mathrm{P}$ forms, especially for the higher values related to intensive agricultural practices, were also observed by Roger et al. (2014). The Broye region is well-known in Switzerland for intensive cropping practices, which are likely to induce a high $\mathrm{K}_{\mathrm{W}}$ fertility status. Sites with significant high $\mathrm{K}_{\mathrm{W}}$ content (red circles in Fig. 5a) matched "rich" $(n=14)$ and "very rich" $(n=4)$ fertility classes, with few "satisfying" sites $(n=5)$. However, many spatial outliers (violet circles in Fig. 5a) were scattered across this cluster and corresponded to sites that were deemed "limited" $(n=8)$ and "poor" $(n=2)$, with few "satisfying" sites ( $n=$ 4). After investigation of the crop rotation of these respective sites, it appeared that high value sites were associated with crops requiring high $\mathrm{K}$ supplies (e.g. sugar beet, maize, potato, tobacco, vegetables), whereas low value sites presented more extensive crop rotation, i.e. areas dominated by cereals and temporary grasslands (data not shown). This suggested that, despite an overall high $\mathrm{K}_{\mathrm{W}}$ fertility status of the region, spatial variability of $\mathrm{K}_{\mathrm{W}}$ was still important and directly related to management practices.

The cluster located to the south of the Gruyère Lake (blue circles in Fig. 5) corresponds to the most elevated and steepest area of the Alpine range located in the Fribourg canton. In this region, along the Sarine valley, mountain pastures were situated far from farms and extensively grazed during summer. Fertilization was likely to be nonexistent in these parcels, leading to an overall poor $\mathrm{K}$ status. This alpine region of the canton was differentiated from the eastern part of the Fribourg Alps, around the Schwarzsee Lake and the Sense River, where mountain pastures were also predominant but had no spatial dependence according to their K status (Fig. 5). Despite a similar land use (Fig. 1), local topography was relatively flat and pastures were located in the vicinity of farms, which was likely to induce regular manure application. Similarly to the Broye region, spatial clusters were related to local fertilization management. Interestingly, for both $\mathrm{K}$ forms high-low relationships were located on the transitions zones with regards to parent material, topography and land use, suggesting a complex interaction between these factors. On the other hand low-high relationships were mostly located within the Broye region known intensive cropping systems pointing more towards the role of management practices. After this primary investigation of the spatial structure of $\mathrm{K}$ forms across the FRIBO network, predictive maps of soil $\mathrm{K}$ forms of the Fribourg canton were built and their relevance for agronomical perspectives was evaluated.

\subsection{Spatial prediction of soil potassium forms}

\subsubsection{Spatial autocorrelation between environmental variables for $K$ forms modeling}

In a previous study from the same area, Roger et al. (2014) found that many of the environmental predictors of $P$ forms, especially terrain attributes, were highly correlated. However, for step-wise multiple regression analysis (MLR) and random forest (RF) initially all environmental variables were tested for $\mathrm{K}$ forms predictions (Tables 2 and 3 ). The assumption was that terrain attributes, although autocorrelated, may represent different processes at hillslope scale that affect $\mathrm{K}$ form spatial distributions differently. For example, steeper slopes occurred at higher elevations, however some of the mountain pasture land at higher elevations (>900 m) was relatively flat with slopes lower than $25 \%$, which were comparable with slopes on croplands occurring at much lower elevations (420-600 m).

The MLR and RF for total and available $\mathrm{K}$ forms predictions further reduced the number of environmental variables based on their significance and contribution to the prediction (Tables 2 and 3). For the MLR, models with the lowest AIC and environmental variables significant at $p \leq 0.05$ were selected. The standard least square (SLS) values indicated that elevation was statistically a significant contributor to spatial predictions of total and available $\mathrm{K}$ forms (Table 2). The
Table 2

Summary results of the step-wise multiple linear regression (MLR) analysis of K forms.

\begin{tabular}{|c|c|c|c|c|c|}
\hline $\mathrm{K}$ form & Selected predictors & $\mathrm{RC}(\mathrm{SLS})^{\mathrm{b}}$ & $p$-Value & ${ }^{\mathrm{d}} \mathrm{Adj} \mathrm{R}^{2}$ & K-fold $\mathrm{R}^{2}$ \\
\hline \multirow[t]{4}{*}{$\mathrm{K}_{\mathrm{T}}$} & Intercept & 41.71 & $<0.0001$ & 0.40 & 0.38 \\
\hline & Parent material & -11.52 & $<0.0001$ & & \\
\hline & Elevation & -0.003 & $<0.0001$ & & \\
\hline & VTR $^{\mathrm{c}}$ & 25.90 & 0.0083 & & \\
\hline \multirow[t]{4}{*}{$\mathrm{K}_{\mathrm{AAE}}^{\mathrm{a}}$} & Intercept & -2.12 & $<0.0001$ & 0.05 & 0.02 \\
\hline & Land use & 0.38 & 0.0031 & & \\
\hline & Elevation & -0.001 & 0.0339 & & \\
\hline & $\mathrm{NH}^{\mathrm{c}}$ & 0.49 & 0.0158 & & \\
\hline \multirow[t]{7}{*}{$\mathrm{K}_{\mathrm{W}}^{\mathrm{a}}$} & Intercept & -1.52 & 0.0406 & 0.13 & 0.16 \\
\hline & Land use & 0.41 & 0.0092 & & \\
\hline & Elevation & -0.001 & 0.0503 & & \\
\hline & $\mathrm{GD}^{\mathrm{c}}$ & 0.002 & 0.0177 & & \\
\hline & $\mathrm{SH}^{\mathrm{c}}$ & -0.001 & 0.2765 & & \\
\hline & $\mathrm{NH}^{\mathrm{c}}$ & 1.04 & 0.0150 & & \\
\hline & $\mathrm{TWI}^{\mathrm{c}}$ & -0.09 & 0.1111 & & \\
\hline
\end{tabular}

\footnotetext{
a In the case of $\mathrm{K}_{\mathrm{AAE}}$ and $\mathrm{K}_{\mathrm{W}}$, the step-wise MLR analysis was performed on logit transformed K contents (see Material and methods, Section 2.4.2).

b RC (SLS): regression coefficient of the respective predicators according to standard least square.

c The following abbreviations were used for the predicators: VTR - Vector Terrain Ruggedness; NH - normalized height; SH - standardized height; GD - gradient distance; TWI - Topographic Wetness Index.

d Adjusted $\mathrm{R}^{2}$ refers to the coefficient of determination computed on the whole dataset, whereas K-fold $\mathrm{R}^{2}$ was computed according to the Leave one Out Cross Validation.
}

significance of elevation indicates, though indirectly, the important role that climate (precipitation and temperature) as a soil forming factor may play on $\mathrm{K}$ forms. Interestingly, soil parent material was the major contributor to spatial prediction of $\mathrm{K}_{\mathrm{T}}$ while land use was important for both available $\mathrm{K}$ forms. This was also the case for the RF model (Table 3) and therefore supported the observations made in Sections 3.1 and 3.2. Historical land use has been shown to modify the available forms of nutrients such as P (Roger et al., 2014.; Lemercier et al., 2008; Reijneveld et al., 2010; Jia et al., 2011), and present results indicate that both land use and parent material influence $\mathrm{K}$ forms. Other studies (Loganathan et al., 1995; Schneider, 1997, 2003; Simonsson et al., 2007) have shown that the release and fixation of $\mathrm{K}$ forms is related to

Table 3

Summary results of the random forest (RF) analysis of K forms.

\begin{tabular}{|c|c|c|c|c|}
\hline $\mathrm{K}$ form & Selected predictors & $\operatorname{MSE}^{\mathrm{b}}(\%)$ & Node purity $^{\mathrm{d}}$ & K-fold $\mathrm{R}^{2}$ \\
\hline \multirow[t]{4}{*}{$\mathrm{K}_{\mathrm{T}}$} & Elevation & 10.80 & 331 & \multirow[t]{4}{*}{0.29} \\
\hline & Parent material & 8.30 & 328 & \\
\hline & Slope & 3.70 & 99 & \\
\hline & $\mathrm{VTR}^{\mathrm{C}}$ & 1.90 & 88 & \\
\hline \multirow[t]{4}{*}{$\mathrm{K}_{\mathrm{AAE}}^{\mathrm{a}}$} & Land use & 4.70 & 48,353 & \multirow[t]{4}{*}{0.08} \\
\hline & $\mathrm{GD}^{\mathrm{c}}$ & 4.10 & 103,561 & \\
\hline & $\mathrm{PLC}^{\mathrm{C}}$ & 3.50 & 128,010 & \\
\hline & Elevation & 3.30 & 129,817 & \\
\hline \multirow[t]{8}{*}{$\mathrm{K}_{\mathrm{W}}^{\mathrm{a}}$} & Slope & 3.27 & 5525 & \multirow[t]{8}{*}{0.08} \\
\hline & Land use & 3.18 & 6350 & \\
\hline & Elevation & 2.99 & 10,934 & \\
\hline & $\mathrm{TR}^{\mathrm{c}}$ & 2.52 & 5983 & \\
\hline & $\mathrm{GD}^{\mathrm{c}}$ & 2.46 & 11,065 & \\
\hline & $\mathrm{PLC}^{\mathrm{C}}$ & 2.43 & 13,237 & \\
\hline & $\mathrm{PRC}^{\mathrm{C}}$ & 2.16 & 7370 & \\
\hline & $\mathrm{TWI}^{\mathrm{C}}$ & 2.12 & 9637 & \\
\hline
\end{tabular}

${ }^{a}$ In the case of $\mathrm{K}_{\mathrm{AAE}}$ and $\mathrm{K}_{\mathrm{W}}$, the $\mathrm{RF}$ analysis was performed on logit-transformed $\mathrm{K}$ contents.

b MSE - mean square error.

c The following abbreviation were used for the predicators: VTR - Vector Terrain Ruggedness; NH - normalized height; GD - gradient distance; TWI - Topographic Wetness Index; PLC - Plan Curvature; PRC - profile curvature; TR - Terrain Ruggedness.

d Node purity indicates how much MSE or Impurity increases when that variable is randomly permutated. Small changes from one variable to another means that little gain in prediction is made by randomly permutating that variable. 
Table 4

Semi-variogram parameters from step-wise multiple linear regression, ordinary kriging and random forest.

\begin{tabular}{|c|c|c|c|c|c|c|c|c|}
\hline $\mathrm{K}$ form & $\begin{array}{l}\text { Nugget } \\
\mathrm{Co}\end{array}$ & $\begin{array}{l}\text { Partial sill } \\
\text { C }\end{array}$ & $\begin{array}{l}\text { Sill } \\
(\mathrm{Co}+\mathrm{C})\end{array}$ & Nugget/sill ratio & Range [m] & $\mathrm{AIC}^{\mathrm{a}}$ & RMSE $^{\mathrm{a}}$ & Function \\
\hline \multicolumn{9}{|c|}{ Step-wise multiple linear regression (MLR) } \\
\hline $\mathrm{K}_{\mathrm{T}}$ & 2.43 & 7.63 & 10.06 & 0.24 & 32,785 & 71.9 & 0.52 & Gaussian \\
\hline $\mathrm{K}_{\mathrm{AAE}}$ & 0.99 & 0.20 & 1.19 & 0.83 & 50 & 13.4 & 0.20 & Exponential \\
\hline $\mathrm{K}_{\mathrm{W}}$ & 0.11 & 0.08 & 0.19 & 0.58 & 18,928 & -101.8 & 0.03 & Gaussian \\
\hline \multicolumn{9}{|c|}{ Ordinary kriging $(\mathrm{OK})$} \\
\hline $\mathrm{K}_{\mathrm{T}}$ & 3.50 & 15.8 & 19.30 & 0.18 & 43,915 & 6.9 & 0.18 & Gaussian \\
\hline $\mathrm{K}_{\mathrm{AAE}}$ & 0.97 & 0.1 & 1.07 & 0.91 & $<0.01$ & 13.4 & 0.20 & Exponential \\
\hline $\mathrm{K}_{\mathrm{W}}$ & 2.50 & 8416 & 8418 & 0.00 & $2,938,627$ & 55.0 & 0.40 & Gaussian \\
\hline \multicolumn{9}{|c|}{ Random forest $(R F)$} \\
\hline $\mathrm{K}_{\mathrm{T}}$ & 1.20 & 12.40 & 13.60 & 0.09 & 46,293 & 6.4 & 0.20 & Gaussian \\
\hline $\mathrm{K}_{\mathrm{AAE}}$ & 0.27 & 0.02 & 0.29 & 0.93 & $<0.01$ & -106.1 & 0.03 & Exponential \\
\hline $\mathrm{K}_{\mathrm{W}}$ & 0.46 & 49.60 & 50.06 & 0.01 & $24,077,475$ & -95.5 & 0.03 & Exponential \\
\hline
\end{tabular}

a The abbreviations AIC and RMSE stand respectively for Akaike Information Criterion and root mean square error.

fertilizer application and soil parent material. The validation results showed that, overall, the selected environmental predictors were only able to explain $40 \%$ and $29 \%$ of the spatial variability of $\mathrm{K}_{\mathrm{T}}$ for MLR and $\mathrm{RF}$, respectively (Tables 2 and 3 ). For the available $\mathrm{K}$ forms, between 5 and $16 \%$ of the variability only could be explained by the selected environmental variables. This is not surprising, and other authors (Mallarino, 1996) have also found that the spatial variability of soil available $\mathrm{K}$ is influenced by management practices and display clustering and cyclic patterns related to fertilizer applications. This suggests that the spatial patterns of available K form may vary locally within short distances depending on management practices, such as fertilization in this case.

\subsubsection{The spatial prediction of $K$ forms based on different interpolations}

The nugget/sill ratio obtained for different $\mathrm{K}$ forms indicated that spatial dependency varied from $<1 \%$ to $91 \%$ (Table 4 ). Based on the scale edified by Cambardella et al. (1994), a nugget/sill ratio of $<25 \%$ suggests a strong spatial dependency, a ratio between 25 and $75 \%$ indicates a moderate spatial dependency, and a value $>75 \%$ indicates a weak spatial dependency. The spatial dependency for $\mathrm{K}_{\mathrm{T}}$ was strong to moderate and relatively consistent between predictive models, varying from 9 to $24 \%$, compared to that of the available $\mathrm{K}$ forms. The exception was $\mathrm{K}_{\mathrm{AAE}}$, which also had a consistent but poor spatial dependency, varying from 83 to $93 \%$ for all three predictive models with higher predictions for the Broye region mostly due to intensive agricultural practices as indicated also by the consistent contribution of land use factor for MLR and RF (Tables 2 and 3). Water extractable $\mathrm{K}$ had the strongest spatial dependency, but only for OK and RF. However, the range of spatial dependency for both
$\mathrm{K}_{\mathrm{AAE}}$ and $\mathrm{K}_{\mathrm{W}}$ was very wide, from 0 to $24,077,475 \mathrm{~m}$ (Table 4 ). The semivariance (Fig. 6 ) of $\mathrm{K}$ forms indicates lack of sill ( $\mathrm{K}_{\mathrm{AAE}}$ ) or a sill that is achieved at a long distance, over $40,000 \mathrm{~m}\left(\mathrm{~K}_{\mathrm{T}}\right.$ and $\left.\mathrm{K}_{\mathrm{W}}\right)$. The wide range suggests that the autocorrelation is not present at scales practical for this study area. For example, the maximum length of the study area is about $36,000 \mathrm{~m}$, which is 3 orders of magnitude smaller than the range value for $\mathrm{K}_{\mathrm{W}}(\mathrm{RF})$. On the other hand, a range value of 0 for $\mathrm{K}_{\mathrm{AAE}}$ for both $\mathrm{OK}$ and $\mathrm{RF}$ (Table 4 ) was associated with a poor spatial dependency and indicates that accurate predictions at finer scales are not attainable and/or realistic.

The spatial distribution shows areas of high $\mathrm{K}_{\mathrm{T}}, \mathrm{K}_{\mathrm{W}}$ and $\mathrm{K}_{\mathrm{AAE}}$ forms mostly around Neuchatel Lake in the northwest portion of the canton (Figs. 7, 8 and 9), in agreement with the LISA maps (Fig. 5). These patterns can partly be explained by partitioning of land uses within the Fribourg canton, which confirms that croplands displayed the highest values for all $\mathrm{K}$ forms, including for $\mathrm{K}_{\mathrm{T}}$ that showed trends with parent material.

These results indicate that the spatial prediction of total and, especially, available $\mathrm{K}$ forms is complex and controlled by factors that exert their influence at different scales. For example, while soil parent materials and land use to a lesser degree may have influenced the spatial distribution of $\mathrm{K}_{\mathrm{T}}$ on a broad scale, land use influenced that of the available $\mathrm{K}$ forms. The interaction between land use and parent material may have resulted in smoother patterns for $\mathrm{K}_{\mathrm{T}}$. However, the relatively sharper boundaries observed for the available $\mathrm{K}$ forms spatial predictions could be related to the more distinct boundaries between different land uses and perhaps even between different management practices within the land use particularly agricultural land. The sensitivity of available forms to farming practices, as compared to the total
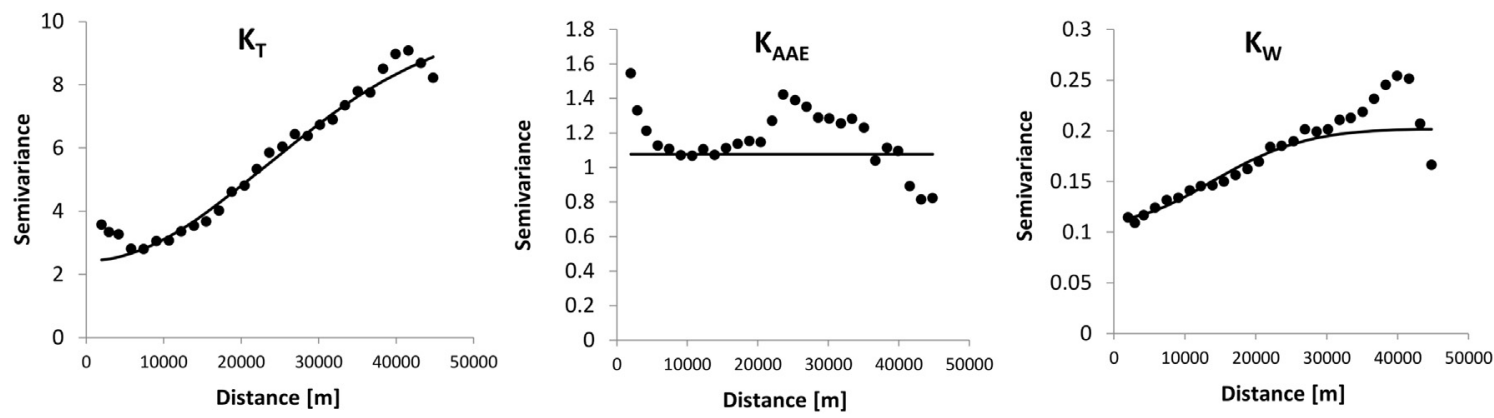

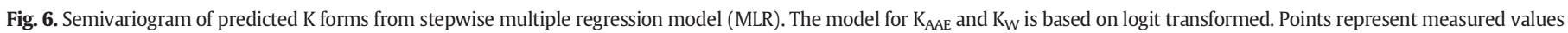
while lines fitted semi-variogram. 

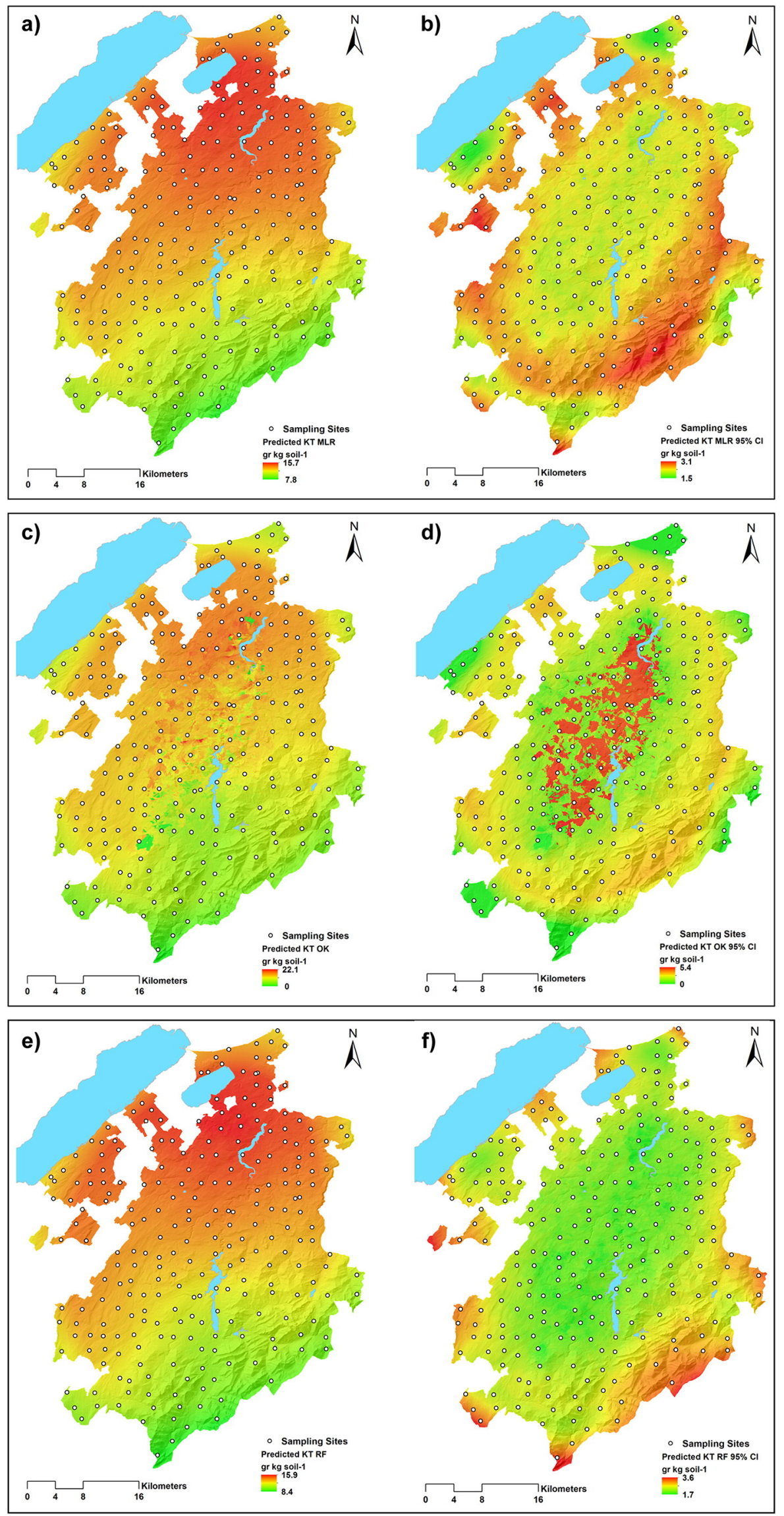

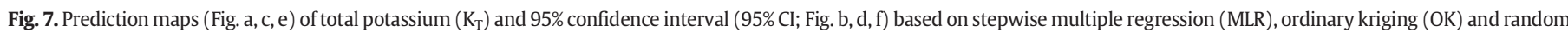
forest (RF). 

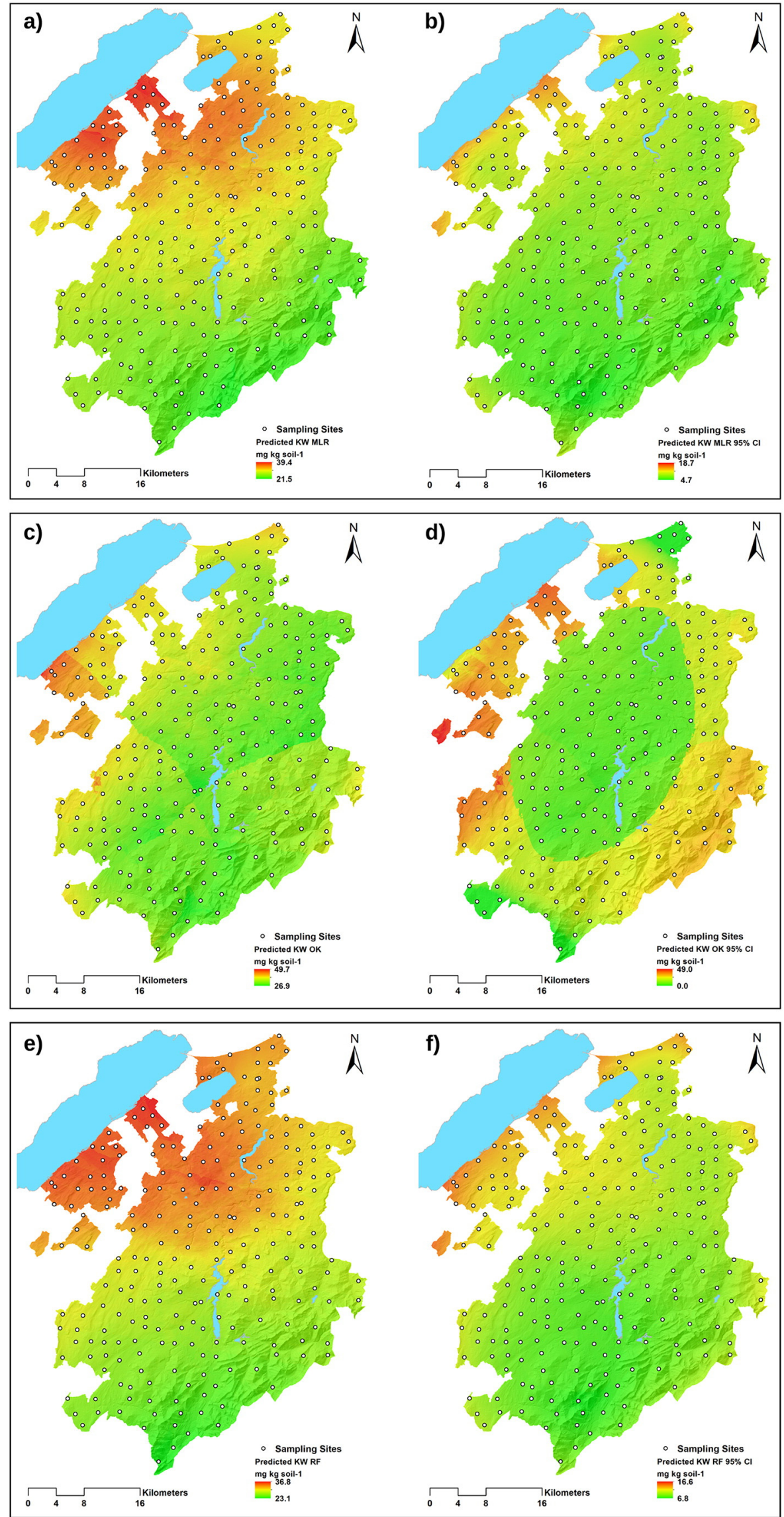

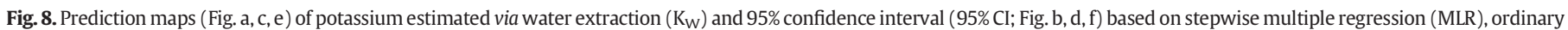
kriging (OK) and random forest (RF). The values are back transformed from logit. 

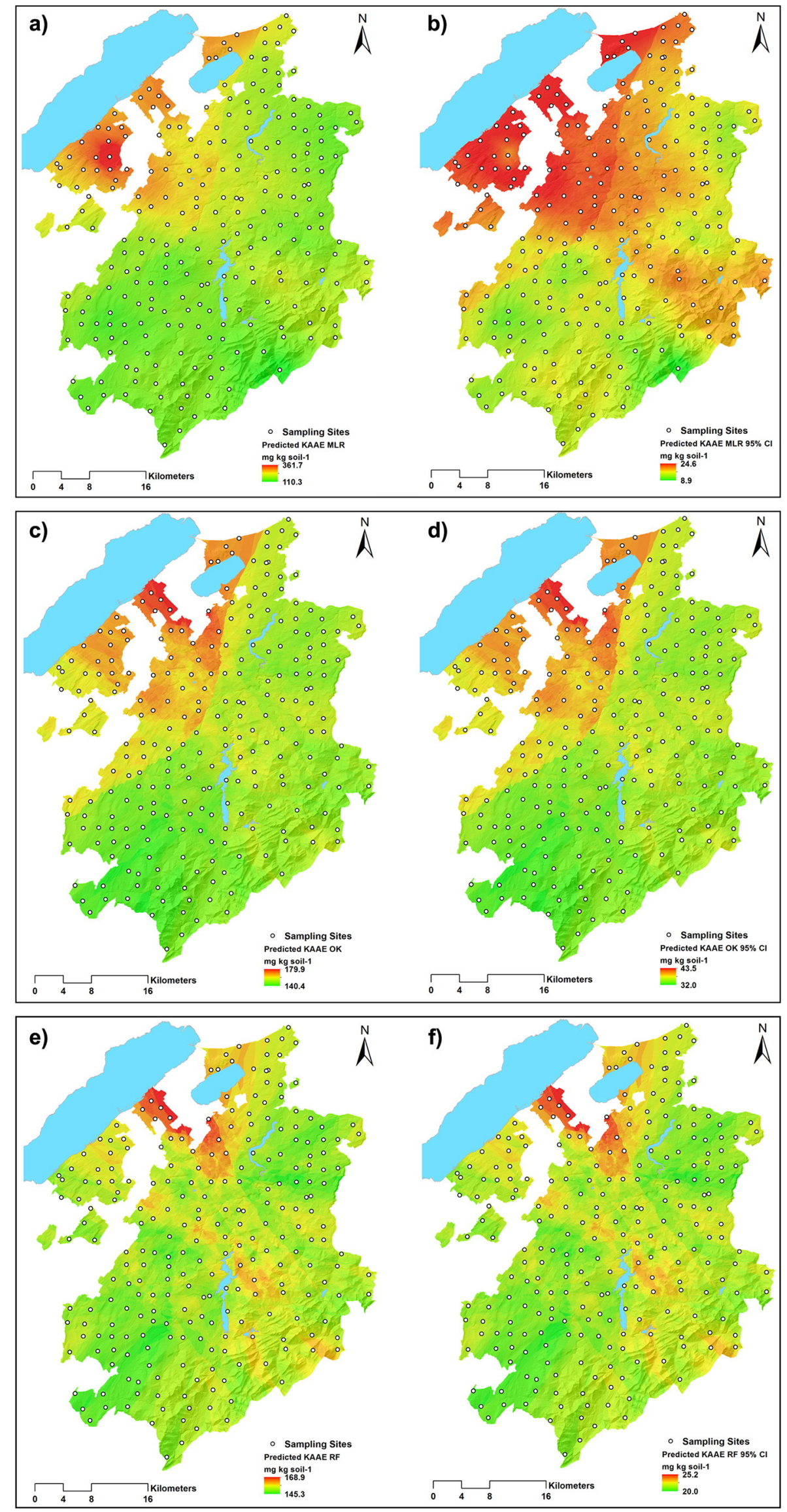

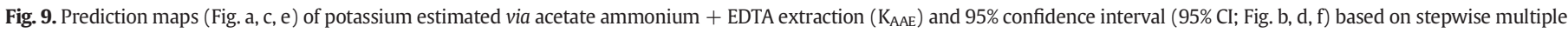
regression (MLR), ordinary kriging $(\mathrm{OK})$ and random forest $(\mathrm{RF})$. The values are back transformed from logit. 
amount of the same element, has important implications for the management, in maintaining adequate and long-term soil nutrients for plant uptake.

\subsubsection{Uncertainty predictions of $\mathrm{K}$ forms}

The 95\% confidence intervals (CI) used to assess the uncertainty predictions were highly variable between predictive models. Ordinary kriging showed the widest ranges for $\mathrm{K}_{\mathrm{T}}$ in both predictive values $\left(0-22 \mathrm{~g} \cdot \mathrm{kg} \mathrm{soil}^{-1}\right)$ and $95 \% \mathrm{CI}\left(0-5.4 \mathrm{~g} \cdot \mathrm{kg}\right.$ soil $\left.{ }^{-1}\right)$ compared to MLR and RF (Fig. 7). This is to be expected due to the fact that both MLR and RF predictive maps are based on predictive values from models that are extrapolated to the grid, as opposed to OK, which uses the actual values for interpolation. Due to model predictions values from both MLR and RF lower values are overestimated and higher values underestimated, as observed by other researchers (Martin et al., 2014) which results overall in smaller ranges for both predicted values and $95 \% \mathrm{CI}$ values. Increasing the sample size to capture the variability in our study area would have allowed for better predictions, however, this was not possible due to the low density of points in our study area (1 per $6.8 \mathrm{~km}^{2}$ ). The $95 \% \mathrm{CI}$ spatial distribution for $\mathrm{K}_{\mathrm{T}}$ from $\mathrm{OK}$ was higher in the central part of the study area (Fig. 7). However, the opposite was the case for MLR and RF with higher $95 \% \mathrm{CI}$ values at the periphery of the Fribourg canton. In a study from the same area using P data from the same observation locations, Roger et al. (2014) noted spatial discrepancies between sample location (approximately $2 \mathrm{~km}$ apart) and terrain-related environmental variables that were derived from a $15 \mathrm{~m}$ resolution DEM, which would be suitable for characterizing spatial distribution of soil properties at landscape scale. Following the suggestion from Roger et al. (2014), spatial resolution was increased from $15 \mathrm{~m}$ to $30 \mathrm{~m}$. However, the uncertainty relative to the predicted values remained high for all interpolation methods, pointing to the inadequacy of the monitoring network density. Overall, the uncertainty for $\mathrm{K}_{\mathrm{W}}$ followed patterns of predicted values and was higher for the western part of the study area (Fig. 8). The 95\% CI range is important for fertilizer recommendations, especially when it is wider that the recommended threshold ranges of fertilizer recommendation guidelines. This underlines the importance of having an appropriate density of observation points in order to improve predictions and potentially reduce errors.

\subsection{Implication of spatial potassium distribution for potassium fertilization}

Across the Fribourg canton, soils generally presented a high $\mathrm{K}$ fertility status. Total K appeared to be present in average quantities (Table 1) and its distribution was mostly influenced by parent material (Fig. 3). However, from a short-term perspective, $\mathrm{K}$ uptake by plants depends essentially on available soil $\mathrm{K}$. The available $\mathrm{K}$ forms proved to be highly variable and considerable across the whole canton and were directly related to on-farm fertilization management, as suggested by variability among land uses (Table 1 ). In particular, $\mathrm{K}_{\mathrm{AAE}}$ was relatively higher in permanent grasslands and mountain pastures (Table 1), both land uses being characterized by the exclusive use of organic amendments. Analysis of spatial autocorrelation (Fig. 5a) and spatial interpolation (Fig. 8) revealed that particularly high levels of $\mathrm{K}_{\mathrm{W}}$ in soils were clustered in the Broye region, likely due to intensive agricultural practices in croplands of this area. In addition, by taking into consideration soil clay content, as proposed in the Swiss fertilization guidelines (Sinaj et al., 2009), it turned out that K over-fertilized sites were encountered in permanent grasslands (Fig. 4), which are mostly located in the central part of the Fribourg canton (Fig. 1). These results are consistent with the outcome of farm nutrient balances in the canton (Rossier et al., 2012) and at the national scale (Spiess, 2011). Despite the fact that $\mathrm{K}$ does not imply detrimental environmental consequences, more attention should be paid to a generalized $\mathrm{K}$ overfertilized status in permanent grasslands as it can increase soil $\mathrm{K}$ leaching, particularly in clayey soils where preferential infiltration flow occurs (Alfaro et al., 2004). Sustainability of K fertilization management could also be improved through specific grassland management. For instance, Alfaro et al. (2004) reported that grazed grasslands are associated with reduced $\mathrm{K}$ leaching in comparison to mown grasslands due to the differentiated timing of fertilizer application. Such practices would allow a reduction in $\mathrm{K}$ applications while guaranteeing sustainable management of the K fertility status. But, this need to be further investigated, as K over-fertilized soils may induce an unbalanced composition of nutrients in grass and consequently increase the risk of $\mathrm{Mg}$ deficiencies and related livestock illnesses, such as hypomagnesaemia, hypocalcaemia or calving issues (Kayser and Isselstein, 2005).

Although spatial statistics highlighted critical regions or specific land uses with regard to soil $\mathrm{K}$ status, the relevance of interpolated maps was limited for in-field or site-specific agronomical purposes. The agronomical appreciation of soil $\mathrm{K}$ status proposed by the Swiss fertilization guidelines (Sinaj et al., 2009) takes into consideration available or exchangeable $\mathrm{K}$ and clay content. However, the $95 \% \mathrm{Cl}$ range of the interpolated maps was too imprecise in comparison to the assessment scale. For instance, according to $\mathrm{K}_{\mathrm{W}}$ soil interpretation, "satisfying" conditions exhibit an amplitude of $c a .14 \mathrm{mg} \cdot \mathrm{kg}^{-1}$ (see footnotes of Fig. 4), depending on soil clay content. In the case of nonsatisfying soil $\mathrm{K}$ conditions, adjustments of $\mathrm{K}$ fertilizer application rates are proposed according to a resolution of $2.5 \mathrm{mg} \cdot \mathrm{kg}^{-1}$, much below the lowest $95 \% \mathrm{CI}$ obtained for the interpolated maps. This highlights the inadequate density of sampling sites of the FRIBO network for direct agronomical purposes, as mentioned by Roger et al. (2014). Thorough studies on more restricted areas (e.g. at watershed or landscape scales) would be of prime interest for determining the appropriate sampling site densities required for local agronomical recommendations. Nevertheless, results presented here show that fertilization management in Switzerland, which relies on local assessment tools (i.e. soil analysis at the plot level and nutrient balance at the farm scale), leads to differentiated $\mathrm{K}$ fertility statuses among land uses of the same region and that a better understanding of $\mathrm{K}$ in fertilization strategies is needed.

\section{Conclusion}

In the Fribourg canton as a whole, large variations of different $\mathrm{K}$ forms (total, exchangeable and available) were observed. Lowland areas were characterized by higher amounts of total $\mathrm{K}$ than the alpine region. No specific spatial patterns related to terrain attributes of the region could be established for exchangeable and available $\mathrm{K}$, and limited areas showed a relatively higher and homogenous available $\mathrm{K}$ status, due to local agricultural management. These results suggest that the distribution of soil $\mathrm{K}$ forms from the upper soil layer $(0-20 \mathrm{~cm})$ were distinctly influenced by (i) soil forming processes (i.e. parent materials and soil types) for total $\mathrm{K}$ and (ii) mostly by land use (i.e. agricultural practices) for exchangeable and available forms. Spatial statistics helped to better understand the relative influence of environmental variables (parent material, soil types, terrain attributes) and land use on the spatial distribution of $\mathrm{K}$ forms, but only at the regional scale. However, predicted maps of $\mathrm{K}$ forms were inadequate for agronomical recommendations due to their high variability and uncertainty predictions of both available and exchangeable $\mathrm{K}$ forms. The overall high $\mathrm{K}$ fertility status observed in permanent grasslands calls for increased attention to $\mathrm{K}$ fertilization management for this land use, as it could lead to an imbalance in the composition of grass nutrients in the long term.

\section{Acknowledgements}

The authors gratefully acknowledge the financial support by Agroscope, Institute for Plant Production Sciences. 
Annex A

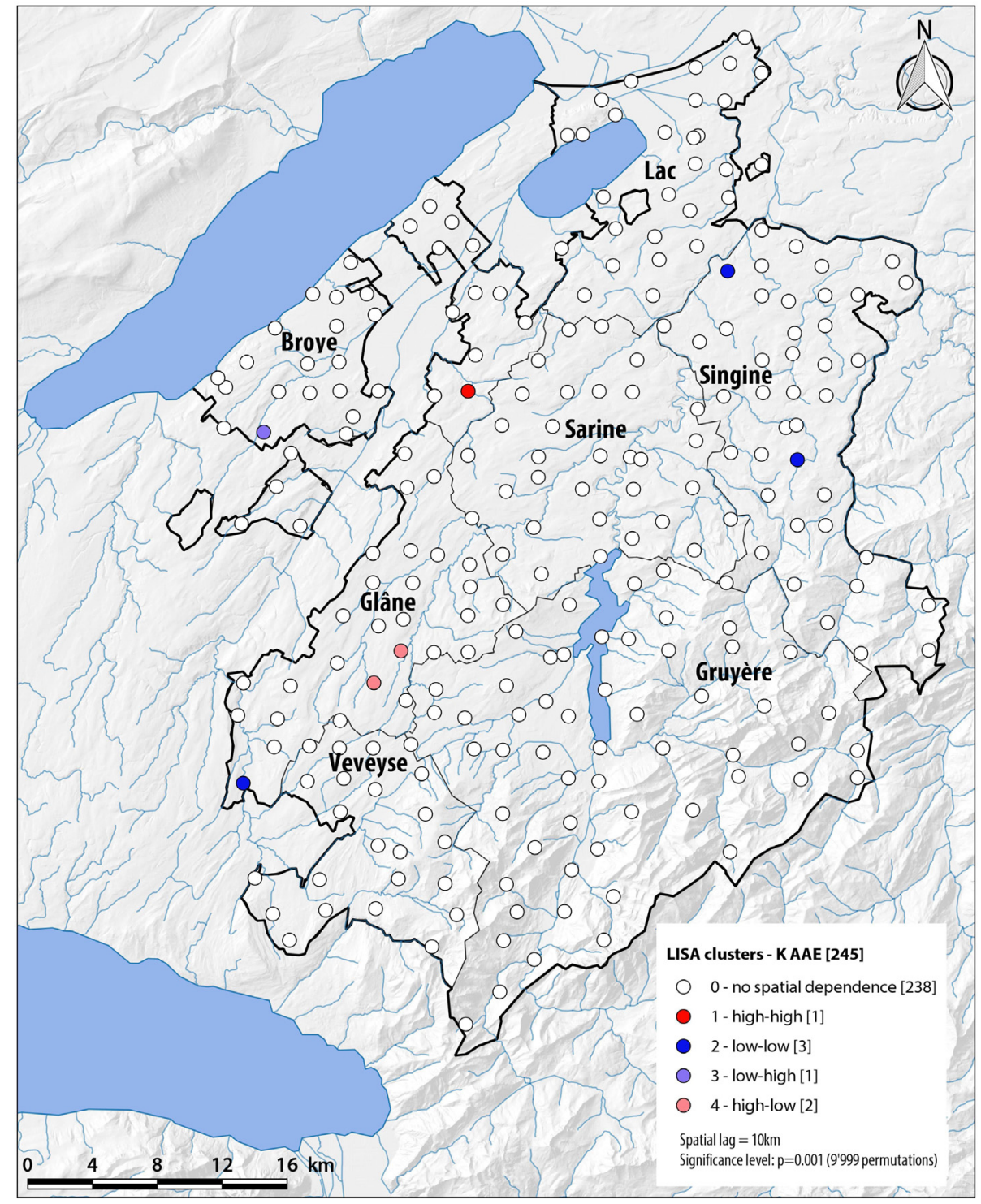

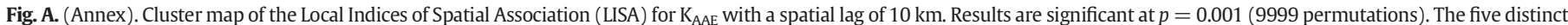

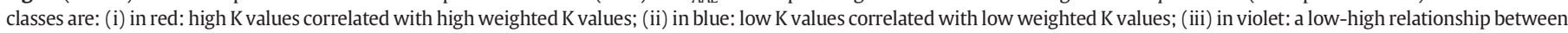

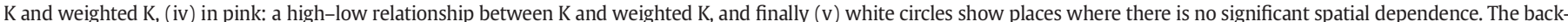

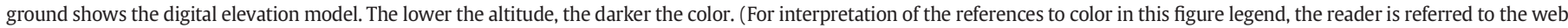
version of this article.)

\section{References}

AFNOR, 1996. NF X31-147: Qualité des sols: sols sédiments, mise en solution totale par attaque acide $12 \mathrm{pp}$.

Akaike, H., 1976. An information criterion (AIC). Math. Sci. 14, 5-9.

Alfaro, M.A., Jarvis, S.C., Gregory, P.J., 2003. Potassium budgets in grassland systems as affected by nitrogen and drainage. Soil Use Manag. 19:89-95. http://dx.doi.org/10. 1111/j.1475-2743.2003.tb00286.x.

Alfaro, M.A., Jarvis, S.C., Gregory, P.J., 2004. Factors affecting potassium leaching in different soils. Soil Use Manag. 20:182-189. http://dx.doi.org/10.1111/j.1475-2743.2004. tb00355.X.

Andrist-Rangel, Y., Simonsson, M., Andersson, S., Öborn, I., Hillier, S., 2006. Mineralogical budgeting of potassium in soil: a basis for understanding standard measures of reserve potassium. J. Plant Nutr. Soil Sci. 169:605-615. http://dx.doi.org/10.1002/jpln. 200621972.

Andrist-Rangel, Y., Hillier, S., Öborn, I., Lilly, A., Towers, W., Edwards, A.C., Paterson, E., 2010. Assessing potassium reserves in northern temperate grassland soils: a perspective based on quantitative mineralogical analysis and aqua-regia extractable potassium. Geoderma 158:303-314. http://dx.doi.org/10.1016/j.geoderma.2010.05.010.

Anselin, L., 1995. Local indicators of spatial association - LISA. Geogr. Anal. 27, 93-115.
Anselin, L., McCann, M., 2009. OpenGeoDa, open source software for the exploration and visualization of geospatial data. Presented at the Proceedings of the 17 th ACM SIGSPATIAL International Conference on Advances in Geographic Information Systems GIS'09. ACM, New York, USA, pp. 550-551.

Askegaard, M., Eriksen, J., Johnston, A.E., 2004. Sustainable management of potassium. In: Schjønning, P., Elmholt, S., Christensen, B.T. (Eds.), Managing Soil Quality: Challenges in Modern Agriculture. CABI Publishing, Wallingford, pp. 85-102.

Barré, P., Velde, B., Fontaine, C., Catel, N., Abbadie, L., 2008. Which 2:1 clay minerals are involved in the soil potassium reservoir? Insights from potassium addition or removal experiments on three temperate grassland soil clay assemblages. Geoderma 146: 216-223. http://dx.doi.org/10.1016/j.geoderma.2008.05.022.

Bertsch, P.M., Thomas, G.W., 1985. Potassium status of temperate region soils. In: Munson, R.D. (Ed.), Potassium in Agriculture, pp. 131-162 Madison, WI.

Blake, L., Mercik, S., Koerschens, M., Goulding, K.W.T., Stempen, S., Weigel, A., Poulton, P.R., Powlson, D.S., 1999. Potassium content in soil, uptake in plants and the potassium balance in three European long-term field experiments. Plant Soil 216, 1-14.

Breiman, L., 2001. Random forests. Mach. Learn. 45:5-32. http://dx.doi.org/10.1023/A: 1010933404324

Brennan, R.F., Bell, M.J., 2013. Soil potassium-crop response calibration relationships and criteria for field crops grown in Australia. Crop Pasture Sci. 64, 514-522. 
Cambardella, C.A., Moorman, T.B., Novak, J.M., Parkin, T.B., Karlen, D.L., Turco, R.F Konopka, A.E., 1994. Field-scale variability of soil properties in central Iowa soils. Soil Sci. Soc. Am. J. 58, 1501-1511.

Chatterjee, S., Santra, P., Majumdar, K., Ghosh, D., Das, I., Sanyal, S.K., 2015. Geostatistica approach for management of soil nutrients with special emphasis on different forms of potassium considering their spatial variation in intensive cropping system of west Bengal, India. Environ. Monit. Assess. 187, 1-17.

Conrad, O., 2006. SAGA - program structure and current state of implementation. In: Böhner, J., McCloy, K.R., Strobl, J. (Eds.), SAGA - Analysis and Modelling Applications, pp. 39-52.

de Mendiburu, F., 2015. Agricolae: Statistical Procedures for Agricultural Research.

FAL, RAC, FAW, 2004. Méthodes de référence des stations fédérales de recherches agronomiques. Agroscope Vol. 2.

Franzen, D.W., Peck, T.R., 1997. Spatial variability of plant analysis potassium levels. Commun. Soil Sci. Plant Anal. 28, 1081-1091.

Ghiri, M.N., Abtahi, A., 2012. Factors affecting potassium fixation in calcareous soils of southern Iran. Arch. Agron. Soil Sci. 58:335-352. http://dx.doi.org/10.1080/ 03650340.2010 .507194$.

Grimme, H., Németh, K., 1978. The evaluation of Soil K status by means of soil testing. Potassium in the Soil/Plant Root System. Presented at the 11th Congress of the International Potash Institute. International Potash Institute, Bern, Switzerland, pp. 61-70.

Hengl, T., Heuvelink, G.B.M., Stein, A., 2004. A generic framework for spatial prediction of soil variables based on regression-kriging. Geoderma 120:75-93. http://dx.doi.org/ 10.1016/j.geoderma.2003.08.018

Hseung, Y., 1980. General aspects of the soils in China (No. 1). Soil Research Report. Institute of Soil Science, Academia Sinica, Nanjing, China.

Jalali, M., 2007. Spatial variability in potassium release among calcareous soils of western Iran. Geoderma 140:42-51. http://dx.doi.org/10.1016/j.geoderma.2007.03.013.

Jia, S., De, Z., Xu, D., 2011. The temporal and spatial variability of soil properties in an agricultural system as affected by farming practices in the past 25 years. J. Food Agric. Environ. 9, 669-676.

Ji-yun, J., 1997. Soil potassium and potassium fertilizer use in northern China. Better Crops Int. $11,16$.

Johnston, A.E., Goulding, K.W.T., 1990. The use of plant and soil analyses to predict the potassium supplying capacity of soil. Presented at the Development of K-fertilizer Rec ommendations, 22nd Colloquium of the International Potash Institute, pp. 153-180.

Kayser, M., Isselstein, J., 2005. Potassium cycling and losses in grassland systems: a review. Grass Forage Sci. 60:213-224. http://dx.doi.org/10.1111/j.1365-2494.2005.00478.x.

Kessler, J., 1997. Potassium: l'excès est nocif. Rev. UFA, pp. 46-47.

Khan, S.A., Mulvaney, R.L., Ellsworth, T.R., 2014. The potassium paradox: implications for soil fertility, crop production and human health. Renew. Agric. Food Syst. 29, 3-27.

Kozar, B., Lawrence, R., Long, D.S., 2002. Soil phosphorus and potassium mapping using a spatial correlation model incorporating terrain slope gradient. Precis. Agric. 3 : 407-417. http://dx.doi.org/10.1023/A:1021549107075.

Lauzon, J.D., O'Halloran, I.P., Fallow, D.J., von Bertoldi, A.P., Aspinall, D., 2005. Spatial variability of soil test phosphorus, potassium, and pH of Ontario soils. Agron. J. 97:524. http://dx.doi.org/10.2134/agronj2005.0524.

Lemercier, B., Gaudin, L., Walter, C., Aurousseau, P., Arrouays, D., Schvartz, C., Saby, N.P.A Follain, S., Abrassart, J., 2008. Soil phosphorus monitoring at the regional level by means of a soil test database. Soil Use Manag. 24:131-138. http://dx.doi.org/10. 1111/j.1475-2743.2008.00146.x.

Liaw, A., Wiener, M., 2002. Classification and regression by randomForest. R News 2 $18-22$.

Loganathan, P., Dickson, A.A., Isirimah, N.O., 1995. Potassium supplying capacity of soils formed on different geological deposits in the Niger Delta region of Nigeria. Geoderma 65:109-120. http://dx.doi.org/10.1016/0016-7061(94)00033-7.

Malakouti, M.J., 1999. Iran confronts the imbalances in fertilizer use. Balanced Fertilization and Crop Response to Potassium. Presented at the International Symposium of the Soil and Water Research Institute. International Potash Institute, Basel, Switzerland, I. R. Tehran, Iran, pp. 11-25.

Malavolta, E., 1985. Potassium status of tropical and subtropical region soils. In: Munson, R.D. (Ed.), Potassium in Agriculture, pp. 163-200 Madison, WI.

Mallarino, A.P., 1996. Spatial variability patterns of phosphorus and potassium in no-tilled soils for two sampling scales. Soil Sci. Soc. Am. J. 60:1473. http://dx.doi.org/10.2136/ sssaj1996.03615995006000050027x.

Mallarino, A.P., Wittry, D.J., Barbagelata, P.A., 2003. New soil test interpretation classes for potassium. Better Crops 87, 12-14.

Marschner, P. (Ed.), 2012. Marschner's Mineral Nutrition of Higher Plants, third ed. Academic Press, San Diego.

Martin, M.P., Orton, T.G., Lacarce, E., Meersmans, J., Saby, N.P.A., Paroissien, J.B., Jolivet, C., Boulonne, L., Arrouays, D., 2014. Evaluation of modelling approaches for predicting the spatial distribution of soil organic carbon stocks at the national scale. Geoderma:223-225 http://dx.doi.org/10.1016/j.geoderma.2014.01.005.

McBratney, A.B., Odeh, I.O.A., Bishop, T.F.A., Dunbar, M.S., Shatar, T.M., 2000. An overview of pedometric techniques for use in soil survey. Geoderma 97:293-327. http://dx.doi. org/10.1016/S0016-7061(00)00043-4.

McLean, O., Watson, M.E., 1985. Soil measurements of plant-available potassium. In: Munson, R.D. (Ed.), Potassium in Agriculture, pp. 277-308 Madison, WI.

Minasny, B., McBratney, A.B., 2002. VESPER.

Moran, P.A., 1950. Notes on continuous stochastic phenomena. Biometrika 37, 17-23.

Öborn, I., Andrist-Rangel, Y., Askekaard, M., Grant, C.A., Watson, C.A., Edwards, A.C., 2005. Critical aspects of potassium management in agricultural systems. Soil Use Manag. 21:102-112. http://dx.doi.org/10.1111/j.1475-2743.2005.tb00114.x.
Odeh, I.O.A., McBratney, A.B., Chittleborough, D.J., 1994. Spatial prediction of soil properties from landform attributes derived from a digital elevation model. Geoderma 63, $197-214$

Odeh, I.O.A., McBratney, A.B., Chittleborough, D.J., 1995. Further results on prediction of soil properties from terrain attributes - heterotrophic cokriging and regression kriging. Geoderma 67, 215-226.

Oksanen, J., Blanchet, F.G., Kindt, R., Legendre, P., Minchin, P.R., O'Hara, R.B., Simpson, G.L., Solymos, P., Stevens, M.H.H., Wagner, H., 2015. Vegan: Community Ecology Package.

R Core Team, 2014. R: A Language and Environment for Statistical Computing. R Foundation for Statistical Computing, Vienna, Austria.

Reijneveld, J.A., Ehlert, P.A.I., Termorshuizen, A.J., Oenema, O., 2010. Changes in the soil phosphorus status of agricultural land in The Netherlands during the 20th century. Soil Use Manag. 26:399-411. http://dx.doi.org/10.1111/j.1475-2743.2010.00290.x.

Rezapour, S., Samadi, A., Jafarzadeh, A.A., Oustan, S.H., 2010. Impact of clay mineralogy and landscape on potassium forms in calcareous soils, Urmia region. J. Agric. Sci. Technol. 12, 495-507.

Roger, A., Libohova, Z., Rossier, N., Joost, S., Maltas, A., Frossard, E., Sinaj, S., 2014. Spatial variability of soil phosphorus in the Fribourg canton, Switzerland. Geoderma 217-218:26-36. http://dx.doi.org/10.1016/j.geoderma.2013.11.001.

Römheld, V., Kirkby, E.A., 2010. Research on potassium in agriculture: needs and prospects. Plant Soil 335:155-180. http://dx.doi.org/10.1007/s11104-010-0520-1.

Rossier, N., Bongard, L., Von Niederhäusern, A., 2012. FRIBO - Réseau fribourgeois d'observation des sols 1987-2011. Institut Agricole de l'Etat de Fribourg, IAG.

Schneider, A., 1997. Release and fixation of potassium by a loamy soil as affected by initial water content and potassium status of soil samples. Eur. J. Soil Sci. 48, 263-271.

Schneider, A., 2003. Characterisation of soil potassium supply as derived from sorptiondesorption experiments. Plant Soil 331-341.

Schroeder, D., 1978. Structure and weathering of potassium containing minerals. Potassium in the Soil/Plant Root System. Presented at the Proceedings of the 11th Congress of the International Potash Institute. International Potash Institute, Basel, Switzerland, pp. 43-63.

Signer, C., Gorin, G., Pugin, A., Wildi, W., 2000. Investigation of a glacial outwash sequence on the Swiss plateau using high resolution seismic reflection. [Etude d'une séquence fluvioglaciaire sur le plateau suisse à l'aide de sismique réflexion à haute résolution]. Quaternaire 11:207-217. http://dx.doi.org/10.3406/quate.2000.1670.

Simonsson, M., Andersson, S., Andrist-Rangel, Y., Hillier, S., Mattsson, L., Öborn, I., 2007. Potassium release and fixation as a function of fertilizer application rate and soil parent material. Geoderma 140:188-198. http://dx.doi.org/10.1016/j.geoderma. 2007.04.002.

Sinaj, S., Mächler, F., Frossard, E., 1999. Assessment of isotopically exchangeable zinc in polluted and nonpolluted soils. Soil Sci. Soc. Am. J. 63, 1618-1625.

Sinaj, S., Richner, W., Flisch, R., Charles, R., 2009. Données de base pour la fumure des grandes cultures et des herbages (DBF-GCH). Rev. Suisse Agric. 41, 1-98.

Sparks, D.L., 1987. Potassium dynamics in soils. Adv. Soil Sci. 6, 1-63.

Sparks, D.L., 2001. Dynamics of K in soils and their role in management of K nutrition. Presented at the IPI PRII K in Nutrient Management for Sustainable Crop Production in India. International Potash Institute, New Dehli, India, pp. 79-101.

Spiess, E., 2011. Nitrogen, phosphorus and potassium balances and cycles of Swiss agriculture from 1975 to 2008. Nutr. Cycl. Agroecosyst. 91:351-365. http://dx.doi.org/ 10.1007/s10705-011-9466-9.

Srinivasarao, C., Vittal, K.P.R., Tiwari, K.N., Gajbhiye, P.N., Kundu, S., 2007. Categorisation of soils based on potassium reserves and production systems: implications in $\mathrm{K}$ management. Aust. J. Soil Res. 438-447.

Syers, J.K., 2003. Potassium in soils: current concepts. In: Johnston, A.E. (Ed.), Feed the Soil to Feed the People - The Role of Potash in Sustainable Agriculture. Presented at the IPI Golden Jubilee Congress. International Potash Institute, Basel, Switzerland, pp. 1952-2002.

Tóth, G., Jones, A., Montanarella, L., 2013. The LUCAS topsoil database and derived information on the regional variability of cropland topsoil properties in the European Union. Environ. Monit. Assess. 185:7409-7425. http://dx.doi.org/10.1007/s10661013-3109-3.

Übersax, A., Schüpbach, H., 2004. Nutrient balancing at the farm level: the Swiss experience. Land Use Systems in Grassland Dominated Regions. Presented at the Proceedings of the 20th General Meeting of the European Grassland Federation, Luzern, pp. 1193-1195.

Van Diest, A., 1978. Factors affecting the availability of potassium in soils. Potassium in the Soil/Plant Root System. Presented at the Proceedings of the 11th Congress of the International Potash Institute, Bern, Switzerland, pp. 37-61.

Webster, R., Oliver, M.A., 2007. Geostatistics for Environmental Scientists, Statistics in Practice. Wiley.

Wilding, L.P., Drees, L.R., 1983. Spatial variability and pedology. In: Wilding, L.P., Smeck, N.E., Hall, G.F. (Eds.), Pedogenesis and Soil Taxononomy.

Winzeler, H.E., Owens, P.R., Joern, B.C., Camberato, J.J., Lee, B.D., Anderson, D.E., Smith, D.R., 2008. Potassium fertility and terrain attributes in a fragiudalf drainage catena. Soil Sci. Soc. Am. J. 72, 1311-1320.

Zhang, H.M., Xu, M.M., Zhang, W.J., He, X.H., 2009. Factors affecting potassium fixation in seven soils under 15-year long-term fertilization. Chin. Sci. Bull. 54:1773-1780. http://dx.doi.org/10.1007/s11434-009-0164-9.

Zörb, C., Senbayram, M., Peiter, E., 2014. Potassium in agriculture - status and perspectives. J. Plant Physiol. 171:656-669. http://dx.doi.org/10.1016/j.jplph.2013.08.008. 